
MINOR PATIENTS AND MEDICAL PRACTITIONERS DURING THE PROCESS OF MEDICAL TREATMENT

Summary of the Doctoral Thesis for obtaining the degree of a Doctor of Law Subsection - Legal Science 


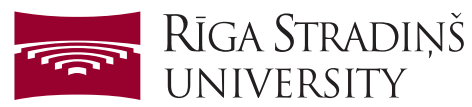

Karina Palkova

\section{THE PROBLEMS OF LEGAL RELATIONS OF MINOR PATIENTS AND MEDICAL PRACTITIONERS DURING THE PROCESS OF MEDICAL TREATMENT}

Summary of the Doctoral Thesis for obtaining the degree of a Doctor of Law

Subsection - Legal Science

Riga, 2019 
Doctoral Thesis has been developed at Rīga Stradiņ̌̌ University.

Research supervisor:

Dr. iur., Assistant Professor Inga Kudeikina,

Rīga Stradiňš University, Latvia

Official reviewers:

Dr. iur., Professor Sandra Kaija,

Rīga Stradiņš University, Latvia

Dr. iur., Professor Ingrīda Veikša,

Turība University, Latvia

Dr. iur., Professor Nataliya O. Gutorova,

Yaroslav Mudryi National Law University, Ukraine

Defence of the Doctoral Thesis will take place at the public session of the Doctoral Council of Legal Sciences on 3 January 2020 at 12.00 in Hippocrates Lecture Theatre, 16 Dzirciema Street, Rīga Stradiņš University.

The Doctoral Thesis is available in the RSU library and at RSU webpage: www.rsu.lv.

Secretary of the Doctoral Council:

Dr. iur., Professor Sandra Kaija 


\section{CONTENT}

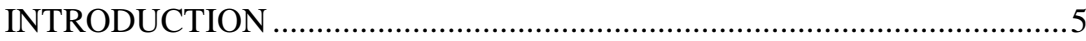

1. BASIC PRINCIPLES OF PROTECTION OF THE RIGHTS OF A MINOR PERSON AND INTERACTION THEREOF WITH THE IMPLEMENTATION OF THE RIGHTS OF MINOR PATIENTS

2. SPECIAL STATUS OF MINOR PATIENTS IN THE TREATMENT PROCESS AND CHARACTERISTICS THEREOF

3. CURRENT ISSUES IN THE PROCESS OF IMPLEMENTATION OF THE RIGHTS OF MINOR PATIENTS AND SOLUTIONS THEREOF

4. CHARACTERISTICS OF THE RIGHTS OF MEDICAL PRACTITIONERS IN TREATMENT OF MINOR PATIENTS, PROBLEMS AND SOLUTIONS THEREOF

5. LEGAL CHARACTERISTICS AND PROCEDURAL SOLUTIONS RELATED TO DISPUTES BETWEEN MINOR PATIENTS AND MEDICAL PRACTITIONERS

CONCLUSION 65

LIST OF LITERATURE AND INFORMATION SOURCES 83 


\section{ABBREVIATIONS}

ANO - United Nations Organisation

Biomedical Convention - Convention on the Protection of Human Rights and

Dignity in Biology and Medicine

ECHR - European Court of Human Rights

EU - European Union

cent. - century

LV - Republic of Latvia

etc. - et cetera

Charter of Fundamental Rights - Charter of Fundamental Rights of the European Union 


\section{INTRODUCTION}

Interest in health care issues of legal nature in Latvia is increasing. Special link of health care with legal science, information on medical - legal science, information on medical - legal grounds of mutual relations of medical practitioners and patients is of interest not only among general public, but also among scientists and professionals.

Legal practice of both foreign countries and Latvia demonstrates a trend of paying special attention to respecting rights of minor patients in health care. On the one hand, it is a positive and development-oriented process. On the other hand, as the rights of the minor patients expand, increased information and legal burden lies on medical practitioners involved in treatment of minor patients. Transformation of the legal status of a minor patient and medical practitioner develops, identifying new directions in mutual legal relations between the parties.

Interpretation, perception and practical application of legal norms both by patients and medical practitioners is considered an especially complicated problem in health care service. The process is particularly complicated by the issue of implementation of rights and interests of minor patients upon receiving health care services. Special status of minor patients in health care process affects not only the protection of rights and interests of a patient but also activities of medical practitioners involved in the treatment. Quality protection of interests and implementation of rights of minor patients and medical practitioners is based on sufficient level of legal awareness not only by the persons themselves, but also by their representatives. As the results of a survey conducted by the author (Annex 1) demonstrate, medical practitioners lack knowledge regarding rights of minor patients in the treatment process.

Based on the study, there are numerous problems with patient awareness level in regard to implementation of their rights, which in turn indicates a 
potentially negative perspective in relations of patients and medical practitioners ${ }^{1}$. Despite that, today there is lack of research, which would provide information on the awareness level of medical practitioners about patient rights, in particular, the rights of minor patients. By analysing works dedicated to the rights of minor patients, it was established that there is lack of conceptual approach to improvement of the rights and interests of minor patients. Simultaneously, there is no tendency to develop a systemic approach in the matter on improvement of legal relations between medical practitioners and minor patients. Medical practitioners are involved in the process of protecting the rights and interests of minor patients in health care. But the level of legal awareness of medical practitioners regarding the scope of rights of minor patients and implementation of these rights is insufficient to ensure the highest level of legal protection. Faults of medical - organisational nature about the improvement of the situation under the context of aforementioned legal relations are identified not only on the scale of medical institutions, but also at municipal and national level.

The topicality of the doctoral thesis consists of:

1) The identification of the collision between the basic principles of children's rights and patient rights, that create problems in applying legal regulations;

2) the definition of minor patient rights in the process of treatmeny and the determination of the legal scope;

3) proposals for the necessity of legal framework that corresponds to international law in the medical treatment process have been identified;

\footnotetext{
${ }^{1}$ National Health Service. Study of patient satisfaction with quality of health care services. Riga, 2018. Available: http://www.vm.gov.lv/images/userfiles/Prezent\%C4\%81cija_VM.pdf [accessed on 09.03.2019].
} 
4) systemical resarch of the issue of the rights and duties of medical practitioners in the context of ensuring rights of the minor patient during the medical treatment.

The theoretical importance of the doctoral thesis is expressed as the examination and analysis of the legal relations between minor patients and medical practitioners, resulting in creation of theoretical findings, for example, on the problem of determining the degree of maturity of a minor patient, on the awareness of patients during the medical treatment process, on the role of the medical practitioners in the esuring the rights of minor patients, on the rights of the minor patient to refuse treatment, etc.that are compiled in the conclusion of the Doctoral thesis.

The theoretical importance of the doctoral thesis is expressed as the examination and analysis of the legal relations of minor patient and medical practitioner, resulting in creation of theoretical findings, for example, on the problem of determining the degree of maturity of a minor patient, on the awareness of patients during the medical treatment process, on the role of the medical practitioners in the esuring the rights of minor patients, on the rights of the minor patient to refuse treatment, etc.that are compiled in the conclusion of the Doctoral thesis.

The practical importance of the doctoral thesis is expressed as a collection of practical findings, which create proposals for the improvement of legal relations between minor patients and medical practitioners, offering specific amendments to the legal acts. The author of the doctoral thesis has published 12 scientific publications with the themes related to the doctoral thesis.

Promocijas darba izpētes objekts ir nepilngadīgo pacientu, ārtsniecības personu un ārstniecības procesā iesaistìto personu tiesiskās attiecības ārstniecības procesā.

The subject of the doctoral thesis is the legal framework of minor patient and medical practioner rights during the medical treatment. 
Research questions of the doctoral thesis:

1. What are the legal principles governing the legal content of a "minor patient" law institute?

2. What is the relationship between the procedural rules governing the exercise of the rights of the minor patient and the actual exercise of the rights of the minor patient in the course of medical treatment?

3. What is the legal and factual impact of medical practitioners on the rights of minor patients and their implementation in the treatment process?

4. What is the preferred means of resolving disputes between outpatient and minor patients?

In order to complete the tasks of the doctoral thesis and to achieve the objective of the doctoral thesis, the author used several research methods: comparative method, synthesis and analysis method, theoretical modeling method, deductive and inductive method, analytical method. The research also used empirical research method - survey.

In order to complete the tasks of the doctoral thesis and to achieve the objective of the doctoral thesis, the author is using general scientific methods in the research work such as analysis, synthesis, modelling, comparative method, inductive and deductive method, analytical method, methods of interpretation of legal norms - grammatical, teleological, historical, as well as empirical method - survey.

The comparative method is used to review and study the institute of rights of minor patients and rights and obligations of medical practitioners in Latvia and other EU member countries. The comparative method allows examining positive cases from other countries, and, possibly, applying the obtained information to improve situation in Latvia. Additionally the comparative method is used in analysis of opinions of various authors on the implementation of the rights of minor patients and institute of obligation of medical practitioners in the process of treatment of a minor patient. 
Synthesis and analysis methods were used at the recommendation and conclusion development stage, which allowed finding interconnections by studying legal acts, court judgements and other documents used during the work, which concerned different approach of minor patient and medical practitioners in implementation of their rights.

Theoretical modelling method was used for illustration of legal norms and to prove possible action steps.

Deductive and inductive methods were also used in research. Deductive method was used to discuss individual legal aspects from the wide range of available theoretical findings and generalizations. Whereas the inductive method was used to draw general conclusions on the basis of practical cases.

Analytical method was used to study international, national and foreign legislation, practice of EHRC and Latvian courts, case law, legal doctrines and other available materials of legal practice. Literature in Latvian, English and Russian was used within the framework of research.

The doctoral thesis also uses such legal provision interpretation methods as, historical, grammatical and teleological, which were used to evaluate and explore the legal rules and the text.

Historical method is used to determine definition of a minor patient and basic principles of minor patients. Upon studying the issue of rights of minor patients in treatment process, historical meaning and development stages of the relevant term has significant meaning. The research is focused on the origins of the aforementioned definition and impact of the historical meaning on the contemporary understanding of the concept. Considering the stages of historical development, during the transformation of legal processes it is possible to express and model the future vision in development of the specific issue and pay special attention to forecasting development of rights of the minor patients. 
Grammatical interpretation method was used to clarify the meaning of the legal norms from the linguistic perspective and to explain the understanding of words and concepts.

Teleological interpretation method was used to explain the meaning of the legal norms, considering their goal, which would have to be achieved. This method was used to evaluate conformity of the content of legal norms to their application.

Theoretical base of the study is constituted by contemporary Latvian and foreign scientific works. So far no books, article were published in the topic of rights of medical practitioners and minor patients in Latvia. Such scientists as J.Silverman, C. Newdick, E. Jackson, S. Ghosh, A. Clapham, I. Kennedy, A. Grubb, G. Williams, M. Knowles, Joan B. Kelly, E. Ushakov, and G. Kolokonov have provided global contribution to the development of contemporary medical law, including the relations of the patients and medical practitioners.

The structure of doctoral thesis consists of five chapters and sub-chapters and final part, which includes conclusions and proposals, as well as list of resources and annexes of the thesis. The structure of the thesis is based on several directions, comprised by study of the institute of rights of minor patients, institute of rights and obligations of the medical practitioners, legal interrelations of the minor patients and medical practitioners and the resulting issues.

The aforementioned structure of the thesis has been selected to, first, identity characteristics and problems of the special status of minor patient, as well as the role of medical practitioners and the subjects, affecting their activities, under the context of ensuring rights and interests of minor patients.

The research results have been approved in international scientific conferences in Latvia and abroad. The author has given oral presentation at 14 international and 2 local conferences, in which she presented both oral and standing research papers. 
- Oral presentation "Robotics in Healthcare and patient's rights". Rīgas Stradiņš University International Interdisciplinary conference on social sciences “PLACES”, Rīga Stradin̄š University, 2019., Riga, Latvia.

- Oral presentation "Legal regulations in the practice of Latvian medical practitioners". International Scientific Conference "Emerging Trends in Economics, Culture and Humanities (etECH2018), The University of Economics and Cultures/Alberta college, 2018, Riga, Latvia.

- Oral presentation "Medical personnel's legal awareness as the key of principal quality of work with minor patients". The $12^{\text {th }}$ International Scientific Conference "SOCIETY. INTEGRATION. EDUCATION." (SIE2018), Rezekne Academy of Technologies, 2018., Rezekne, Latvia.

- Oral presentation "Medical practitioner's legal regulations in the practice from Urban-Rural Development perspective". The 7th International Interdisciplinary Scientific Conference "SOCIETY.HEALTS.WELFARE." Contemporary Social Dynamics and Wealfare: Urban and Rural Development Perspectives. Rīga Stradiņš University, 2018., Riga, Latvia.

- Oral presentation "The legal aspects of operation of the State Sports Medicine Center, aimed at the care of children with increased physical activity and control of doping". Internation scientifical-practical conference "Legal issues in the Centenary of Latvia: Retrospective and Perspective", Rigas Stradinš University, 2018., Riga, Latvia.

- Oral presentation "Legal aspects of quality communication in the communication of medical practitioners and minor patients”. Rigas Stradiņš university scientific conference. Rīga Stradiṇš University, 2018., Riga, Latvia.

- Oral presentation "Mediator's personality in specific legal disputes: sports related disputes and healthcare related disputes”. ”. Rigas Stradiņ̌s university International scientific-practical conference "The directions of 
modernizing the legal system: the real status and future perspectives". 2017., Riga, Latvia.

- Oral presentation "Policy documents on patients rights in Latvia". The 59 th International Scientific Conference of Daugavpils University. 2017., Daugavpils, Latvia.

- Auditor: International workplace learning conference "Patient safety in clinical practice - the reality and challenges in the 21 st century", Rigas Stradin̄š University, 2016. Riga, Latvia

- Oral presentation "The Right to Health in context of ensuring the best interests of the child". The 6th International Interdisciplinary Scientific Conference "SOCIETY.HEALTS.WELFARE." Living in the world of Divercity: Social Transformations, Innovations, Solutions.” Rīga Stradiņš University, 2016., Rīga, Latvija.

- Oral presentation "Mediation in helathcare disputes in Latvia". The 58th International Scientific Conference of Daugavpils University. 2016., Daugavpils, Latvia.

- Oral presentation "The problems of legal framework in the medical treatment process of minors”. Rigas Stradinš University, 2016. Scientific conference, "Transformation of political, economical, social and legal system in Latvia and the world. Rīga Stradiņš University, 2016., Riga, Latvia.

- Oral presentation "Consent to treatment and anamnesis as problem of communication with minor patients in healthcare decision-making". The 10th International Congress on social Sciences, Complutence University, 2016., Madrid, Spain.

- Presentation "Medical personnel professional liability insurance as a form of legal and social responsibility". The 6th International Conference on Humanities and Social Sciences ICHSS, 2016., London, United Kingdom. 
- Oral presentation "Issues of Legal Organization of the Patient-Health Care Professional Relationship". ICSS XIII 8th International Conference on Social Sciences, EUSER, ICCV - Romanian Academy, 2016., Sofia, Bulgaria.

- Oral presentation "Rights of the minor patients and analysis of problems". IV International Scientific Conference "Transformational Processes in Law, Regional Economics and Economic Policies:Topical Economic, Political and Legal issues", Baltic international Academy, 2015., Riga, Latvia.

The author has published 12 scientific publications on the related subjects of the study in internationally reviewed collections of scientific articles. Some of the published articles were included in the databases of internationally quoted scientific articles: Web of Science and EBSCO.

Scientific publications related to the topic of doctoral thesis:

- "Medical Personnel's Legal Awareness as the Key of Principal Quality of Work with Minor Patients." $12^{\text {th }}$ International scientific conference "SOCIETY. INTEGRATION. EDUCATION. Proceedings of the International Scientific Conference. Rezekne Academy of Technologies, 190-198, 2018. (http://journals.ru.lv/index.php/SIE/article/view/3165) (Web of science).

- "Overview and analysis of legal regulations in medical practitioners practice." International Scientific Conference "Emerging Trends in Economics, Culture and Humanities (etECH2018) Conference abstracts Proceedings. Riga: The University of Economics and Culture/Alberta College, 44., 2018.

- "Medical practitioner's legal regulations in the practice from Urban-Rural Development perspective". International Conference Society. Health. Welfare. 9.lpp., 2018. (article submitted). Accepted for publication (Web of Sciences).

- "The right to health in context of ensuring the best interests of the child" (co-author Dr.iur, I.Kudeikina), Proceedings of the Conference "Society. 
Health. Welfare. p.8. 2018, SHS Web of Conferences 51, 01015. Indexed in Google Scholar, Crossref. Accepted for publication (Web of Sciences).

- "Policy documents on patients' rights in Latvia", Proceedings of the 59th International scientific conference of Daugavpils University. Daugavpils Universitātes Akadēmiskais apgāds "Saule", 2017. ISBN 978-9984-14-833-5. Published: https://dukonference.lv/files/proceedings_of_conf/978-9984-14-8335_59_konf_kraj_B_Soc\%20zin.pdf (EBSCO).

- "Mediator's personality in specific legal disputes: sports related disputes and healthcare related disputes" (co - author M. Kamenecka Usova). Acta Universitatis Danubius. Juridica, Vol 13, No 2/2017. Published: http://journals.univ-danubius.ro/index.php/juridica/article/view/3947

- "Consent to treatment and anamnesis as problem of communication with minor patients in healthcare decision-making process". (Co-author Semaka S.) European Journal of Interdisciplinary studies, V. 2, n. 3, p. 57-62, aug. 2016. ISSN 2411-4138.

Published: http://journals.euser.org/index.php/ejis/article/view/1887. Indexed in Google Scholar, Crossref

- "Medical personnel professional liability insurance as a form of legal and social responsibility". (Co-author Kudeikina I.) Academic Journal of Interdisciplinary studies MCSER Publishing, Rome, Italy, 2016, ISSN 228813993, Vol 5 No 3S1. ISSN 2281-3993.

Published: www.mcser.org/journal/index.php/ajis/article/download/ 9799/9437. Indexed in Google Scholar, Crossref

- "Possibilities for application of mediation in health care field", Collection of electronic scientific articles of the Faculty of Law of RSU SOCRATES, No 3(3), 2015. (https://www.rsu.lv/sites/default/files/imce/ Dokumenti/izdevumi/socrates_3_2015.pdf)

- "Rights of minor patients in treatment process and problems thereof", Collection of scientific articles on the basis of proceedings of IV 
International practical conference "Transformation process in law, regional economics and economic politics: current problems of economical-political and legal relations”. Baltic International Academy, 2016.

- "Mediation in Latvian healthcare system". Proceedings of the 58th International Scientific Conference of Daugavpils University. Daugavpils Universitātes Akadēmiskais apgāds "Saule", 2016., ISBN 978-9984-14-779-6 (ISSN 978-9984).

Published: https://dukonference.lv/files/proceedings_of_conf/978-998414-779-6_58\%20konf\%20kraj_B_Soc\%20zin.pdf

- "Issues of Legal Organization of the Patient - Health Care Professional Relationships", (Co-author Kudeikina I.) European Centre for science education and research, Conference proceedings, ICSS VIII, European Journal of Multidisciplinary Studies, 2016, ISSN 2414-8385. 


\section{BASIC PRINCIPLES OF PROTECTION OF THE RIGHTS OF A MINOR PERSON AND INTERACTION THEREOF WITH THE IMPLEMENTATION OF THE RIGHTS OF MINOR PATIENTS}

Unlike the history of rights of minor patients, the history of protection of the rights of minor patients has been studied in more depth and more actively. During the earliest development stage of ancient states, the dominant opinion regarding children's rights was a complete power of an adult (most often - the father) over a child of any age. The attitude of the society at the very beginning of this development state demonstrated unequal position of the strong ones or the leaders towards the weaker members of society, including the minors. Later, as the society evolved and developed various skills, for example, making fire, it became necessary to preserve the gains. Then the minors, in particular, like women, were assigned duties - to maintain the source of life of that period, namely - the fire. Since by time the scope of duties entrusted to minor persons increased, it became necessary to train the young generation by passing work and hunting skills to them. As a result, the society transited from instinctive awareness to awareness based on necessity to protect and raise its members. With the appearance of legal norms, there was necessity to apply them to the youngest members of community as well. ${ }^{2}$

The most recent history demonstrates that contemporary protection of children's rights became prominent in the mid- $19^{\text {th }}$ century, when the idea to protect the rights of children as minority was born. Already since 1841, norms that protected the rights of children to education were included in the legislation of France. This trend started to spread all over Europe and, as a result, several

2 Медведев, Г. П. Этика социальной работы (Eng. Ethics of social work). М.: ВЛАДОС, 1999, 21. 
important documents were adopted in the sphere of protection of children's rights $^{3}$. However, it should be noted that one cannot yet speak of protection of children's rights as a fully individual sector. The rights of a child, the same as the rights of an adult person, are human rights. Additionally, the principles of protection of children's rights, which are embedded both at international and national level, apply to a child.

General principles of protection of children's rights are attributable to children and to minor persons, authorities and institutions, which are bound to comply with them. The principles of children's rights are integrated in international and national legislation with the purpose of strengthening protection of a relevant group of persons, without dividing this category of persons in more detail. Therefore, upon considering the principles of children's rights in this study, attention will be paid to the acceptance and compliance with these principles at different levels under the context of minor patients.

The first is the principle of non-discrimination. The concept of discrimination itself is vast and not specific. There are instruments of different nature which give the opportunity to give a more specific and detailed definition of this concept depending on the given legal situation ${ }^{4}$. Nevertheless, the definition of the UN Human Rights Committee is considered to be more complete; it stipulates that discrimination is any form of segregation, exclusion, restriction or advantage that could be justified by any reason, such as race, sex, colour, language, religious, political and other beliefs, national or social origin, property, birth or other status, and the purpose or consequence of which is to limit the recognition, use or exercise of all rights and freedoms by all persons

3 Children's Rights History. Historical Overview of the Children's Rights Evolution. Available: https://www.humanium.org/en/childrens-rights-history [accessed on 13.04.2018].

${ }^{4}$ Besson, S. The Principle of Non-Discrimination in the Convention on the Rights of the Child. The International Journal of Children s Rights, No 13, 2005, 433-461. 
equally ${ }^{5}$. It follows from the definition that non-discrimination clause refers not only to the mentioned fields and situations, but also to any activities which are not mentioned and might not be known at the moment. The aforementioned principle is also attributable to all persons equally, thus, also to minor patients as a group of special persons. It should be noted that the Law on the Protection of the Children's Rights ${ }^{6}$ does not contain any special indication to nondiscrimination of children based on age. At the same time Paragraph 2 of Section 3 of the Law on the Rights of Patients specifically stipulates non-discrimination on the grounds of age. This indicates a different approach regarding the principle of children's rights and application and understanding of the principles of children's rights and rights of minor persons depending on the applied field.

Section 13 of the Law on the Rights of Patients includes limited rights of a minor person to participate in the processes related to treatment, which essentially contradicts the general norm of the Law on the Rights of Patients, as well as Section 2 of the UN Convention on the Rights of the Child and Section 21 of the Charter of Fundamental Rights. The non-discrimination principle within the framework of the Law on the Rights of Patients manifests delegating the mentioned rights to lawful representatives, medical practitioners, Orphan's Court, therefore causing advantage of these persons and institutions.

\section{The second principle, which would be attributable to minor patients,} is the principle of ensuring of interests.

Information on the principle of ensuring best interests of a child is found primarily in the UN Convention on the Rights of the Child. Section 3 of the

\footnotetext{
${ }^{5}$ Human Rights Committee's General Comment 18 on Non-Discrimination, 10/11/1989, HRI/GEN/1/Rev. 5, reproduced in Compilation of General Comments and General Recommendations adopted by Human Rights Treaty Bodies, UN Doc. HRI/GEN/1 (1992). Available: http://www.equaLVightstrust.org/ertdocumentbank/Human\%20 Rights\%20Committee,\%20General\%20Comment\%2018.pdf [accessed on 11.12.2018]. ${ }^{6}$ 08.07.1998. Law on the Protection of the Children's Rights. Latvijas Vēstnesis, $199 / 200(1260 / 1261)$
} 
Convention consists of three parts, the first of which stipulates that "in all actions concerning children, whether undertaken by public or private social welfare institutions, courts of law, administrative authorities or legislative bodies, the best interests of the child shall be a primary consideration"". The principle of ensuring the best interests of the child is one of the most important principles, recognised at the international level ${ }^{8}$. Since child anatomy is not absolute, his or her interests shall be delegated and transferred to third parties. Ensuring the interests of a child is closely linked to the motivation of other physical or legal entities to perform analysis of these interests in adopting of an objective decision.

The principle of ensuring the best interests of a child shall be primary upon implementing various activities, oriented towards minor persons, including minor patients ${ }^{9}$. The UN Convention on the Rights of the Child clearly indicates that the aforementioned principle is activated not only when a decision is made or it is planned to make a decision, which directly affects the interests of the child, but also if the already adopted decision indirectly affects the interests of a child. Therefore, this principle acts both as a material norm and as an explanatory one. Thus, by applying a general principle, several interpretations are possible, but the one applied is the only one which ensures the interests of a child the best ${ }^{10}$.

${ }^{7}$ Declaration of the Rights of the Child, proclaimed by the United Nations General Assembly on 20 November 1959. Available: http://lm.gov.lv/upload/berns_gimene/ bernu_tiesibas/akti/bernu_tiesibu_deklaracija.pdf [accessed on 13.08.2018].

${ }^{8}$ Judgement of the Constitutional Court of the Republic of Latvia of December 22, 2005 in case No 2005-19-01, Available: https://likumi.lv/doc.php?id=124748\&from=off, [accessed on 13.08.2018].

${ }^{9}$ Pobjoy, J. M. The Best Interests of the Child Principle as an Independent Source of International Protection. International Comparative Law Quarterly, 2015, Vol. 64, No 2, p. 330. Available: https://ssrn.com/abstract=2679568 [accessed on 09.10.2018].

${ }^{10}$ Pobjoy, J. M. The Best Interests of the Child Principle as an Independent Source of International Protection. International Comparative Law Quarterly, 2015, Vol. 64, No 2, p. 331. Available: https://ssrn.com/abstract=2679568 [accessed on 09.10.2018]. 
The aforementioned disclaimer of the principle is included also in the national legislation, for example, in Section 6 of the Law on the Protection of the Children's Rights, where Paragraph 1 of the aforementioned section stipulates that in lawful relations that affect a child, the rights and best interests of the child shall take priority. Whereas Paragraph 2 of this Section includes a supplementing norm, which stipulates that in all activities regarding a child, ensuring of the rights and interests of a child shall take priority ${ }^{11}$. By examining the content of the Law on the Rights of Patients, it shall be concluded that Paragraph 10 of Section 10 of the law stipulates among other things that in order to ensure the rights and interests of a minor patient, the state and municipal authorities are entitled to receive contact information regarding family doctor or pediatrist of the minor with the help of link means of the information system ${ }^{12}$. Reference to this principle is also found in Section 13 and Section 14 of the Law on the Rights of Patients, which stipulate the rights of the doctor to make decision on treatment in line with the interests of the minor patient ${ }^{13}$. The principle of ensuring the best interests of the child has not been directly stipulated in the Law on the Rights of Patients, but rather partially integrated in some legal norms.

The principle of ensuring the interests of the child under the context of the rights of minor patients determine the obligation of the lawful representatives of a minor patient and medical practitioners to listen to opinions, beliefs and thoughts of this patient and to involve him or her in decision making, instead of granting the minor patient the rights of an adult or full (unrestricted) rights. Article 12 of the UN Convention on the Rights of the Child does not limit the rights and responsibilities of the lawful representatives of children and minor

${ }^{11}$ 08.07.1998. Law on the Protection of the Children's Rights. Latvijas Vēstnesis, 199/200 $(1260 / 1261$

12 30.12.2009. Law on the Rights of Patients. Latvijas Vēstnesis, No 205(4191)

13 30.12.2009. Law on the Rights of Patients. Latvijas Vēstnesis, No 205(4191) 
patients, upon expressing a subjective opinion on the matters concerning children.

The third principle of protection of the rights of minor patients is the principle of participation, which results both from national legislation and EU legislation. Article 24 of the Charter of Fundamental Rights the children shall have the right to express their views freely and be listened to ${ }^{14}$. Article 5 of the Convention for the Protection of Human Rights and Dignity of the Human Being in Biology and Medicine states that "an intervention in the health field may only be carried out after the person concerned has given free and informed consent to it". Paragraph 2 of Article 6 of this Convention describes in detail the participation rights of a minor person, in particular, stipulating that the opinion of the minor shall be taken into consideration as an increasingly determining factor in decision making ${ }^{15}$.

At the national level, the rights of a child to participation have been primarily defined in the Constitution of the Republic of Latvia, where, it must be admitted, they have not been particularly distinguished. Nevertheless, it results from Section 102, 100 and 99 of the Constitution of the Republic of Latvia that several rights are stipulated therein, and certain activities, which are generally applicable to everyone, without specifying a particular range of persons, and therefore are attributable to children as well.

When analysing the content of Section 13 of the Law on the Rights of the Patient from the perspective of compliance with the principle of participation, there are certain problems and shortcomings in compliance with this principle.

14 Charter of the Fundamental Rights (2012/C 326/02). Available: https:/eurlex.europa.eu/legal-content/LV/TXT/?uri=CELEX\%3A12012P\%2FTXT [accessed on 21.03.2018].

${ }^{15}$ Convention for the Protection of Human Rights and Dignity of the Human Being in Biology and Medicine - Convention on Human Rights and Biomedicine. Adopted on April 4, 1997. Latvijas Vēstnesis, No 205, 30.12.2009. Available: https://likumi.lv/ta/lv/starptautiskie-ligumi/id/1410 [accessed on 21.03.2018]. 
The law mostly includes the rights of participation of the lawful representatives of a minor patient and not the participation rights of a minor patient himself/herself.

The principle of participation of children is also integrated in Section 27 of the Sexual and Reproductive Health Law, which stipulates the rights of a pregnant patient, who is younger than 16 years, to participate in making of the decision on termination of pregnancy ${ }^{16}$. The rights of a minor patient as defined by this section are not absolute either and the participation principle is not fully complied with. The rights of a minor patient to participation are encumbered and restricted by the superiority of lawful representatives and state authorities.

The fourth principle of protection of the rights of minor patients is the principle of ensuring special protection.

The UN Convention on the Rights of the Child has united different children's rights with the main purpose of not only strengthening the children's rights, which have been known to humankind under the context of other contracts and documents, but also to strengthen the human rights, which provide special protection to a child due to the special legal status of the child ${ }^{17}$. Article 3 of the Convention contains reference to the special status of a child in protection of his or her rights, which stipulates that in all actions concerning children, whether undertaken by public or private social welfare institutions, courts of law, administrative authorities or legislative bodies, the best interests of the child shall be a primary consideration. This also applies to activities of court, medical institutions and other state and municipal authorities ${ }^{18}$.

16 19.02.2002. Sexual and Reproductive Health Law. Latvijas Vēstnesis, No 27 (2602), Section 27

${ }^{17}$ Никонов, К. Современные теоретические аспекты института международноправовой защиты и поощрения прав ребенка (Eng. Modern theoretical aspects of the institution of international legal protection and promotion of the rights of a child).

Московский журнал международного права, 2009, № 1, 95-96.

${ }^{18}$ Comments to the Civil Procedure Law. Part II, Chapter 29-60. Prepared by a group of authors under scient. ed. of Prof. K.Torgāns, Riga: Tiesu namu aǵentūra, 2012, p. 74. 
The second principle of the UN Convention on the Rights of the Child determines that special protection shall be ensured to the child on the grounds of law and other means ${ }^{19}$. This has also been reflected in Section 110 of the Constitution of the Republic of Latvia, which stipulates that the state shall protect the rights of the child.

The principle of special protection of the children's rights in Latvia has also been integrated in the Law on the Protection of the Children's Rights. Section 6 of the Law stipulates, the rights of a child is priority and any act or failure to act, as a result of which the rights of a child are not observed, shall be considered amoral and illegal. Whereas Section 17 of this Law stipulates that a child has the right himself or herself or through a lawful representative to take part in the drawing up and realisation of programmes for the protection of the rights of a child. Section 20 of this law also defines a special mechanism for protection of children namely, submissions and complaints that are related to the protection of the rights of a child shall be examined without delay ${ }^{20}$.

Upon considering the Law on the Rights of the Patient from the perspective of special protection of the children, it can be concluded that special protection in this case manifests in different ways - both as positive and negative protection.

Pursuant to Paragraph 8 of Section 5 of the Law on the Rights of the Patient if a minor patient has suspended medical treatment and left a medical treatment institution, the lawful representative of the patient shall be informed immediately, but if such does not exist - the Orphan's Court. Regarding an adult person who does not have any severe health or mental disorders, a record shall

\footnotetext{
19 Declaration of the Rights of the Child, proclaimed by the United Nations General Assembly on 20 November 1959. Available.: http://www.ugf.gov.lv/lat/normativie_akti_ un_attistibas_planosanas_dokumenti/bernu_tiesibu_deklaracija/ [accessed on 19.09. 2018].

20 08.07.1998. Law on the Protection of the Children's Rights. Latvijas Vēstnesis, No $199 / 200(1260 / 1261)$.
} 
be made in medical documentation concerning the leaving of a medical treatment institution. This indicates special protection regulation regarding a minor patient. Possibly this legal norm causes collision which requires evaluating the conflict of principles between the principle of ensuring special protection of a child and, for instance, the principle of ensuring interests of a child. In such case, the principle of ensuring interests of a child shall be applied from the perspective of negative protection model.

Paragraph 10 of Section 10 of the Law on the Rights of the Patient determines application of positive principle of ensuring interests of the child, stipulating that in order to ensure the rights and interests of a minor patient, the state and municipal authorities are entitled to receive contact information regarding family doctor or pediatrist of the minor with the help of link means of the information system. Upon analysing the Law on the Rights of the Patient, it shall be concluded that the principle of ensuring interests of the child has been indirectly included therein. However, legal norms included in the law, which include disclaimer of the special protection of the child, are not straight-forward, namely, the content of these legal norms may be interpreted by applying the principle of non-discrimination of minor patients, principle of ensuring interests or principle of participation.

This indicates that the principle of ensuring interests of a child shall also apply under the context of protection of the rights of minor patients and strengthening of this principle in the sphere of patients' rights will contribute to the development of these rights.

Upon studying the main principles of minor persons, it shall be concluded that these are directly attributable also to a group of special persons - minor patients. At the moment, no legal enactment in Latvia which regulates issues of medical law, provides clear definition of the principles of protection of the rights of minor patients, to which the judicial power and the state and municipal authorities should rely on and refer to in situations when there exists or there 
may arise a dispute between a minor person and a medical practitioner in the field of provision of healthcare services. 


\section{SPECIAL STATUS OF MINOR PATIENTS IN THE TREATMENT PROCESS AND CHARACTERISTICS THEREOF}

Essence of the problems of legal relations of minor patients and medical practitioners lies in lack of understanding of the status of minor patients and specific characteristics in application of this status. Therefore, upon identification of the status of a minor patient and providing explanation of the mentioned status, the mechanism of legal relations between medical practitioners and minor patients should be improved.

The process of formation of the rights of minor patients has been long and complex in terms of legal perspective. Thus, when analysing the status of minor patients, its current understanding and possibilities of implementing the rights of these patients, it is important to understand the institute of rights of children or minor persons in its totality, as well as historical development thereof and to consider the meaning and topicality of the term "patient" today.

Throughout the entire existence of humankind, the status of minors has been defined on the basis of attitude of society and community towards children. The institute of children's freedom of action and its scope depended on social role of children as imposed by adults. Therefore, upon studying the definition of a minor patient, first, the meaning and understanding of such words as "patient" and "minor" should be understood.

Upon studying the word "patient" from the perspective of etymology, with the purpose of identifying its origins and development, as well as the type and meaning of the word, it was established that patient as the subject of law was mentioned already in 1772 BC in Hamurappi laws. The Hamurappi laws contain reference to the damage caused to the patient by medical practitioners, which are 
related to surgical intervention ${ }^{21}$. The word "patient" has originated from Latin words "patior", "pati", "patiens". The word "patiens" is translated as physical and emotional suffering, the one who suffers, who is passive ${ }^{22}$. Thus, the word "patiens" was initially used in reference to a person who was passive and unable to take care of oneself. "Patiens" of the time was not an independent service recipient who could have participated in the treatment process, but rather a person who submitted to doctor's instructions ${ }^{23}$.

Contemporary Latvian language dictionary also contains reference to the origins of the word "patient" ("pacients"). It has been established that the word "patient" in Latvian has been adopted from the Latin word "patiens" (in Latin means: "sufferer") ${ }^{24}$.

Today the word "patient" is used in relations between healthcare service providers and persons receiving the services. For example, pursuant to the Medical Treatment Law, patient is a person who receives healthcare services or seeks them ${ }^{25}$. Whereas it follows from Section 11 of the Law on the Rights of the Patient that a patient is also a person entitled to participate in clinical studies. Therefore, the definition of the term "patient" mentioned in the Medical Treatment Law should be updated.

21 Якобсон, В. А. Законы Хаммурапи как источник по истории древней Месопотамии (Eng. Laws of Hammurabi as a source on history of ancient Mesopotamia): Дис. докт. ист. наук. Ленинградское отделение Института востоковедения, 1987, 94-96.

22 Ašnevica, S., Gusarova, A., Lieljuksis A., u.c. Medicīnas tiesības (Eng. Medical Rights). Rīga: Tiesu nama aǵentūra, 2015, 292.

23 Tallis, R. Do we need a new word for patients? Commentary: leave well alone. BMJ, 1999, Vol 318, No 7200, 1757-1758. Available: https:/www.ncbi.nlm.nih.gov/ pmc/articles/PMC1116090/ [accessed on 12.06.2018].

${ }^{24}$ Ilustrētā svešvārdu vārdnīca (Eng. Illustrated Foreign Word Dictionary). Rīga: Avots, $2005,891$.

${ }^{25}$ 01.07.1997. Medical Treatment Law. Latvijas Vēstnesis, No 167/168 (882/883), 
After evaluating the existing situation, one should partially agree with Dr. Julia Neuberger, who suggested necessity to substitute the word "patient"26. According to Julia Neuberger, the word "patient" is associated with suffering, with certain obligation which the person has to fulfil in order to encourage improvement of its health condition. In this case, it is not possible without involvement of a professional or medical practitioner. In her works, the author notes that the word "patient" indicates inequality in relations between healthcare service provider and a person receiving $\mathrm{it}^{27}$.

Another term which is proposed for substitution of the word "patient" is "consumer". But it is not sufficiently accurate to meet preferences of both scientists and professionals of the industry, when considering change of such socially important term. Under the context of healthcare service provision, the word "consumer" indicates constant performance of activities by health service provider, for example, using medicine, performance of surgeries, which is largely untrue. This fails to reflect the essence of the specific situation, namely, the wide range of services, for example, related to healthy lifestyle and physical activities. It should be noted that activity by patients in healthcare process is not always perceived positively by the service provider, more likely controversially.

Unlike the definition of the term "patient", the definition of a minor patient is not found in scientific literature or applicable laws and regulations of Latvia. Understanding of this definition is formed based on analysis of individual words in applicable laws and regulations.

Upon considering the definition of a minor person from international perspective, it should be noted that pursuant to Article 1 of the Convention on

\footnotetext{
${ }^{26}$ Neuberger, J. Do we need a new word for patients? Lets do away with "patients". BMJ, 1999, Vol. 318, No 7200, p. 1756-1757. Available: https:/www.ncbi.nlm.nih.gov/ pmc/articles/PMC1116090/ [accessed on 09.07.2018].

${ }^{27}$ Neuberger, J. Do we need a new word for patients? Lets do away with "patients". BMJ, 1999, Vol. 318, No 7200, p. 1756-1757. Available: https:/www.ncbi.nlm.nih.gov/ pmc/articles/PMC1116090/ [accessed on 09.07.2018].
} 
the Rights of the Child "a child means every human being below the age of eighteen years". This legal criterion is widely applied by the EU, upon defining the word "child". Definition of a child according to the EU legislation is very vast and may vary depending on a member state.

Upon considering the definition of a minor person or child at national level, it should be noted that it is fragmented and unclear. It shall be concluded from the Section 2019 of the Civil Law, which stipulates that the minority of persons continues until they reach the age of eighteen, that a minor person is a person, who has not reached the age of 18. At the same time Section 220 of the Civil Law stipulates that in exceptional circumstances and for especially good causes, when guardians and closest kin of a minor attest that the behaviour of the minor is irreproachable, and he or she is able to independently protect and defend his or her rights and perform his or her duties, the minor may be declared as being of age of majority even before he or she has reached the age of eighteen, but not earlier than before he or she fully reaches the age of sixteen ${ }^{28}$. The Civil Law stipulates that a person who has entered marriage in accordance with the procedure of the law, before reaching the age of eighteen shall be considered an adult $^{29}$.

Definition of a minor person is identified in Section 64 of the Criminal Law, from which it follows that a minor person is a person who has not reached the age of eighteen years until committing of a criminal offence.

The Latvian Administrative Violations Code also defines the age limit for liability of a minor person. Pursuant to Section 12 of this law persons who have attained 14 years of age on the day of the committing an administrative violation shall be subject to administrative liability.

28 20.02.1937. Civil Law. Law of the Republic of Latvia. Valdības Vēstnesis, 41

29 20.02.1937. Civil Law. Law of the Republic of Latvia. Valdības Vēstnesis, 41 
Paragraph 1 of Section 12 of the Law on Protection of Children's Rights stipulates that a child has the right to acquire a profession and choose employment relevant to it. Educational institutions shall provide professional training, but for children who have attained 15 years of age and are registered as unemployed persons through the national employment service. Whereas Paragraph 1 of Section 3 of this Law defines that a child is a person who has not attained 18 years of age, excepting such persons who have been declared to be of legal age in accordance with the law or have entered into marriage before attaining 18 years $^{30}$. Under this law a minor person has expanded rights already since the age of 15 , namely, the rights to acquire profession and enter in legal employment relations.

Whereas in Section 13 of the Law on the Rights of Patients the age gradation of a minor person is divided below the age of 14 years and starting from 14 years $^{31}$.

It shall be concluded from the above that the concept of a minor person is vast and allows differentiating age thresholds depending on situations which arise in the process of formation of legal relations. Legal framework is not the same for children of different age in terms of stipulating the rights and obligations of a minor person.

The legislator has not specified the term "minor patient". Latvian legislation includes the concept of a minor person and provides explanation thereof, but as far as the definition of a minor patient is concerned, it cannot be found in either special literature or in legal enactments. At the same time, in the matter of implementation of rights of minor persons are divided depending on the age threshold of the minor patient, which is a minor patient below the age of 14 years, starting from 14 years, from 16 years and from 18 years.

\footnotetext{
${ }^{30}$ 08.07.1998. Law on Protection of Children's Rights. Latvijas Vēstnesis, No 199/200 (1260/1261), Ziṇotājs, No 15

31 30.12.2009. Law on the Rights of Patient. Latvijas Vēstnesis, No 205 (4191)
} 
Differentiated division of minor persons, including patients, considering the characteristics of the aforementioned group of persons, causes problems in relations between medical practitioners and minor patients or their lawful representatives. This complex division of patients by age causes ambiguous understanding of the implementation of rights of these patients.

Such vaguely defined age threshold in the matter of minor patients interferes with activities of medical practitioners in the process of provision of healthcare services and causes legal risks in relations of the parties.

Despite the uncertainty of the concept of a minor patient in the Latvian legislation, the rights of the child or minor patient to healthcare are protected by the Constitution. Constitutional rights of a minor person shall be considered in context with the fundamental rights of any person or human rights, which are specified in the Constitution. The constitutional rights of minor patients to health and life are stipulated in Section 111 and 93 of the Constitution of the Republic of Latvia ${ }^{32}$.

Rights of minor patients are vast and are not limited by provisions of the Constitution. Interpretation of these rights allow concluding that minor patient is a unique subject of the law, who has priority entitlement to enjoy the rights and freedoms in healthcare, assigned to it, but due to several legal circumstances, these rights and freedoms may be restricted, considering the characteristics of the minor patient as a subject of the law.

However, if a minor patient represents a group of specially protected persons, the question is about protection of this group at the level of policy planning documents.

The policy of the rights of minor patients hypothetically may be confirmed in basic principles, plans, laws, guideline documents, which is

\footnotetext{
32 01.07.1993. Constitution of the Republic of Latvia: Law of the Republic of Latvia: adopted at the Constitutional Assembly on February 15, 1992 and comes into force on November 7, 1992. Latvijas Vēstnesis, No 43, Section 89, 93
} 
partially true regarding the current situation. The relevant documents shall be examined to provide answer to this question.

Upon reviewing most important policy planning documents of Latvia, it shall be concluded that their content is vast, but information regarding the protection of rights of minor patients at national level is missing. The national policy planning documents largely contain reference to human rights and children's rights, but the rights of the minor patients and the issue of protection of these rights has not been sufficiently defined. Currently, the national level policy planning documents do not meet the requirements of the international law. Pursuant to the instructions of the UN Committee on the Rights of the Child the member countries, including Latvia had to make changes in the national legislation and policy planning documents, providing for basic principles of children's rights in these documents, protecting rights and interests of children ${ }^{33}$. Considering the fact that a minor patient is a special subject of human rights, to which the same basic principles apply as to a child, upon development of the national policy, the policy planning documents should include not only the principles of children's rights, but also the basic principles of protection of the rights of minor patients as priority, in order to encourage protection of the minor patients as a special subject of the law and also based on the provisions of the UN Declaration of the Rights of the Child.

${ }^{33}$ Committee on the Rights of the Child. Thirty-fourth session 19 September-3 October 2003 GENERAL COMMENT No. 5 (2003) General measures of implementation of the Convention on the Rights of the Child (arts. 4, 42 and 44, para. 6). Available: http://www.refworld.org/docid/4538834f11.html [accessed on 13.08.2018]. 


\section{CURRENT ISSUES IN THE PROCESS OF IMPLEMENTATION OF THE RIGHTS OF MINOR PATIENTS AND SOLUTIONS THEREOF}

Upon studying the question of legal relations of minor patients and medical practitioners and legal problems resulting from these relations, attention should be paid to identification of current issues in the process of implementation of the rights of minor patients. Upon analysing the situation in the implementation of the rights of minor patients and studying the principles of protection of the rights of minor patients and the concept of the minor patient, as well as compliance with the rights of the aforementioned subject in other EU member countries, it shall be concluded that there are several problems in Latvia, related to protection of rights of minor patients as a group of specially protected persons. The awareness of patients of the rights assigned to them in medical treatment is relatively low, as demonstrated by recent studies ${ }^{34}$. Only $51 \%$ of respondents admit that they are aware of patient's rights, of which majority or 33 $\%$ have chosen the answer "most probably yes", which indicates incomplete knowledge in this field ${ }^{35}$. Problems related to informing of patients of the rights assigned to them in medical treatment are seen among children and juveniles. Therefore, due to insufficient awareness of minor patients their human rights, namely, the rights to health are infringed, and basic principles of protection of the rights of minor patients are violated. The human rights of any person, the

${ }^{34}$ Putnina, A., Brants, M. Patient satisfaction with the quality of healthcare services: Study. Rīga: SIA «Projektu un kvalitātes vadība» un SIA «Aptauju Centrs», 2019 Available:http://www.vm.gov.lv/images/userfiles/Prezent\%C4\%81cija_VM.pdf [accessed on 18.02.2019].

${ }^{35}$ National Health Service. Study on patient satisfaction with the quality of healthcare services. Riga, 2018. Available: http://petijumi.mk.gov.lv/sites/default/files/title_file/ Zinojums_Pacientu_apmierinatiba_ar_veselibas_aprupes_pakalp_kvalitati.pdf [accessed on 18.02.2019]. 
rights to health etc., are embedded both at international and national level. The stated rights are attributed also to patients and in particular to minor patients, since legal acts regulating this industry do not stipulate specific and special rights of a child as a minor patient, such as in Section 13 of the Law on the Rights of Patient ${ }^{36}$.

Several of such individual rights cause legal problems both in daily work of medical practitioners and in relations between a minor patient, his or her lawful representative and a medical practitioner in the process of providing healthcare services.

There are series of issues in the sphere of implementation of the rights of minor patients, which should be resolved by making corresponding changes in applicable laws and regulations, paying special attention to compliance with these changes in practice. For instance, the applicable laws and regulations of the Republic of Latvia determine that minor persons are entitled to be informed of their health condition. The information provided by medical practitioner shall be not only understandable to the minor patient, but also corresponding to the age and maturity of the patient ${ }^{37}$. Nevertheless, despite regulations of specific issues, there is a series of legal uncertainties in medical treatment of minor persons, which cause or may cause legal problems in provision of healthcare services. Minor patients have incomplete level of patient participation in adoption of decisions, related to treatment process. The scope of information provided to a minor patient is not sufficient and comprehensive ${ }^{38}$, which results from the requirements of international and national legal enactments regarding evaluation of maturity and age or ensuring best interests of a minor patient.

\footnotetext{
36 30.12.2009. Law on the Rights of Patient. Latvijas Vēstnesis, No 205 (4191)

37 30.12.2009. Law on the Rights of Patients. Latvijas Vēstnesis, No 205(4191)

${ }^{38}$ Joseph, F. Fletcher morals and medicine: The moral problems of the Patient's Right to know the truth, contraception, artificial insemination, sterilization, euthanasia. Princeton University Press, 2015, p. 35.
} 
Participation of minor patient in treatment process is an important precondition for successful and productive cooperation for achievement of the common goal among the medical practitioner, the patient and his or her lawful representatives. Participation of patients in adoption of decisions, related to treatment, currently has become a political necessity in many countries and healthcare systems all around the world. Simultaneously, patient participation in health care is closely related to treatment results and improvement thereof ${ }^{39}$.

Patient participation concept in the sphere of healthcare service provision is not a recent invention. Such cooperation of doctor and patient and strengthening thereof was discussed at the normative level already in mid-19 $9^{\text {th }}$ century ${ }^{40}$.

Minor patients as a group of specially protected persons are entitled to special conditions regarding implementation of their rights and freedoms in any sphere, including healthcare, by expressing their opinion or dissatisfaction with the received service. But, despite the aforementioned, as well as positive trends in the legal framework in terms of submission of complaints and proposals, the mechanism of implementation of the rights of minor patients is still incomplete. The process, according to which a minor patient may submit a complaint or proposal regarding treatment process, does not differ from adults ${ }^{41}$.

Medical institutions in Latvia, institutions which control quality of medical treatment process and protection of the children's rights, have not started to work on developing procedure or mechanism of submitting complaints or proposals in line with the rights of minor patients.

\footnotetext{
${ }^{39}$ Thompson, A. G. The meaning of patient involvement and participation in healthcare consultations: A taxonomy. Soc Sci Med, 2007, Vol 64, No 6, p. 1297-310. Available: https://www.ncbi.nlm.nih.gov/pubmed/17174016 [accessed on 10.11.2018].

${ }^{40}$ Collins, A., Britten, S. A., Ruusuvuori, J. Participation in health care consultations: Qualitative perspectives. UK Higher Education OUP Humanities \& Social Sciences Health \& Social Welfare. McGraw-Hill Education (UK), 2007, p. 7.

${ }^{41}$ 08.07.1998. Law on Protection of Children's Rights. Section 70. Latvijas Vēstnesis, No 99/200 (1260/1261), Ziṇotājs, No 15, 04.08.1998.
} 
Considering specifics of minor persons, as well as the level of dependency from lawful representatives, the format of complaints is generally strange. The minor patient's fear of consequences, which may be caused by filing a complaint against a medical practitioner, prevents fully implementing the rights assigned to them. But creation of a mechanism, which would be oriented only and solely towards the rights of minor persons to express complaints or proposals on medical treatment process, would ensure achievement of a new result not only in the sphere of healthcare but also in social sphere. Simultaneously, while working on the development of the system, special attention should be paid to protection of a minor patient, which would protect such patient from potential negative consequences and would ensure positive and objective complaint mechanism.

The information on the rights of a minor person to express dissatisfaction, to file a complaint or proposal regarding work of a medical practitioner, or to express a praise, should be available to minor patients, not only their lawful representatives. Besides, such information should be expressed in a language and style understandable to the minor patient, considering the legal characteristics of the status of this patient.

Determining maturity degree of a minor patient in the treatment process is another pre-condition for emerging of issues.

Article 12 of the Convention on the Rights of the Child specifies the obligation of member states to assure that any child, including a minor patient, has the right to express his or her views, and the views of the child shall be given due weight in accordance with the age and maturity of the child ${ }^{42}$. This article is not only universal, but also a unique condition in the sphere of human rights.

${ }^{42}$ United Nations General Assembly (1989), Convention on the Rights of the Child, adopted on 20 November 1989. Available: https://likumi.lv/ta/lv/starptautiskieligumi/id/1150 [accessed on 16.10. 2018]. 
This norm stipulates the legal and social status of a minor person, which assigns certain rights and obligations to the subject of law ${ }^{43}$.

Maturity level of a minor person is also mentioned in Article 24 of the Charter of Fundamental Rights ${ }^{44}$ and Paragraph 2 of Article 6 of the Biomedical Convention ${ }^{45}$. Paragraph 1 of Section 13 of the Law on the Rights of Patients stipulates that the patient below the age of 14 years shall be entitled to participate in adoption of a decision related to treatment in accordance with his/her age and maturity ${ }^{46}$. Similar regulation is also included in Section 27 of the Sexual and Reproductive Health $\mathrm{Law}^{47}$. Under the context of protection of the rights of minor patients the significance of maturity degree is included in national legislation. The question remains about application of this framework.

Scientific literature provides different definitions of maturity. Maturity definition may be considered both from medical perspective and sociological and psychological perspective. Regardless of the sphere in which the maturity concept is considered, what matters are the framework and the forms of maturity definition. However, there are difficulties with understanding of the definition.

Both international and national legal enactments stipulate the obligation to listen to a minor person and to take the opinion of the aforementioned person into account in accordance with the maturity degree. None of the legal

${ }^{43}$ United Nations Committee on the Rights of the Child. General comment No.12 (2009). The right of the child to be heard. July 20, 2009. Available: http://www.lm.gov.lv/lv/index.php?option=com_content\&view=article\&id=81194 [accessed on 16.10. 2018].

44 EU Charter of Fundamental Rights (2012/C 326/02). Available: https://eurlex.europa.eu/legal-content/LV/TXT/?uri=CELEX\%3A12012P\%2FTXT [accessed on 21.09.2018].

${ }^{45}$ Convention on the Protection of Human Rights and Dignity in Biology and Medicine Convention on Human Rights and Biomedicine. Adopted on April 4, 1997. Latvijas Vēstnesis, No 205, 30.12.2009. Available: https:/likumi.lv/ta/lv/starptautiskieligumi/id/1410 [accessed on 21.11.2018].

${ }^{46}$ 30.12.2009. Law on the Rights of Patients. Latvijas Vēstnesis, No 205 (4191)

47 19.02.2002. Sexual and Reproductive Health Law. Latvijas Vēstnesis, No 27 (2602), Ziṇotājs, No 15 
enactments includes disclaimer regarding the form of determining the maturity degree or the form of maturity. In theory, maturity is considered on several planes. Simultaneously, the maturity of the minor patient may be expressed as behaviour which should meet certain standards, or behaviour which should correspond to the age of the patient and physical development stages, related to the age (organ development, mental development, etc.).

It follows from above that evaluation of maturity is a complex process which, based on national legislation, has been imposed as an obligation on medical practitioners. The process of evaluation of maturity shall consider not only medical characteristics, but also experience of the minor patient, social and economic conditions and psychological conditions. It also indicates complications in determining the degree of maturity.

Medical practitioner shall be aware that determining maturity is based on the ability of a minor patient to formulate his or her opinion, while the opinion is formed on the grounds of information which the patient receives from a medical practitioner. Based on the legislation of the Republic of Latvia, it is not clear what age the minor patient is considered to be sufficiently matured. Accordingly, there is no straight-forward answer to the question from which age the medical practitioner should evaluate the degree of maturity.

It should be noted that, compared to provisions of the EU legislation, in Latvia the degree of maturity is not paid such decisive role to. Regarding case law and court findings, the institute of determining of degree of maturity has not been sufficiently studied in Latvia. Although theoretically maturity has different types and forms, in Latvian legislation maturity is seen as a whole; the legislation does not specify what type of maturity and on what conditions it should be evaluated. That, in turn, highly generalises and complicates cooperation of medical practitioners and minor patients in the treatment process, since ambiguous cooperation mechanism prevents paying sufficient attention to the opinion of a minor patient. 
Ensuring the best interests of a minor patient is also one of the principal issues in provision of healthcare services or interaction of medical practitioners and minor patients. Medical practitioner also has the obligation to ensure the best interests of the child ${ }^{48}$. It follows that the rights of minor patients to ensuring best interests should be provided in the healthcare sphere as well. Ensuring such rights primarily depends on the competence of medical practitioners. The rights of a minor patient to ensuring the best interests under the context of health care present a challenge to medical practitioners. The rights of a minor patient to ensuring the best interests are not interpreted and understood in a narrow and isolated manner, but rather in common context with the rights and obligations of medical practitioners, as well as obligations of a minor patient in the treatment process, which simultaneously result from the international legislation and also interests of society in general ${ }^{49}$.

The concept "best interests" is wide and therefore provides opportunity for vast interpretation. Therefore, in the field of medical law and especially in relations of medical practitioners and minor patients the aforementioned concept is defined from various aspects, and interpretation thereof is sometimes contradicting.

Despite medical practitioners being bound to comply with the best interests of minor patients in their activities, this institute is not mentioned in the Medical Treatment Law either. This indicates that the "best interests" of children, including minor patients, have general nature, since these rights are not embedded in special legal enactments, but only in the Constitution of the Republic of Latvia, the Civil Law, etc.

48 30.12.2009. Law on the Rights of Patients. Section 13, Paragraph 3. Latvijas Vēstnesis, No 205 (4191)

${ }^{49}$ Bowyer, L. The ethical grounds for the best interest of the child. Cambridge Quarterly of Healthcare Ethics, 2016, vol 25, No 1, p. 63-69. 
The definition of best interests is also not mentioned in international law. The UN Convention on the Rights of the Child explains the institute of children's rights in substance, provides a clear explanation of what children's rights are, but it does not stipulate the institute of best interests of the child. The Convention provides for an important role in ensuring of the best interests of the child, but definition and interpretation thereof is not sufficient.

The term "best interests of the child" is widely discussed and interpreted not only among medical practitioners but also among lawyers.

In order to introduce some clarity about ensuring and complying with the rights of a minor patient to ensuring best interests in medical treatment, changes need to be made in legal enactments, regulating this sphere, for example, the Law on the Rights of Patients and the Medical Treatment Law, by defining the concept of ensuring the best interests of a minor patient to prevent using its understanding in general manner, i.e., too widely.

In order to create a common approach to the concept of ensuring best interests in healthcare, the author offers to discuss the mentioned definition with professionals of the industry, judges, lawyers and Orphan's Courts.

Another issue, which causes series of problems, is the rights of the lawful representative (natural guardian) of a minor patient and characteristics of the legal nature thereof in medical treatment process.

The whole body of rights of lawful representatives of minor patients is primarily oriented towards protection of the rights of such patients. Lawful representatives act on behalf of the minor patient during the medical treatment process; therefore, their contact with a medical practitioner directly affects the process of treatment.

The Law on the Rights of Patients specifies situations, when the rights of a minor patient shall be represented through a lawful representative. Paragraph 1 and 3 of Section 13 of this law stipulates the cases, upon occurrence of which, the lawful representative is entitled to make decisions on treatment of a minor 
patient ${ }^{50}$. It should be noted that by the age of 14 the minor patient in Latvia is not entitled to decide on medical treatment but may only participate in adoption of the related decision, which is participation of informative nature ${ }^{51}$.

The obligation of lawful representatives - parents of a minor patient is to take care of protection of their interests, including participation in the treatment process and representing the minor patient in relations with a medical practitioner. Essentially these trilateral relations (minor patient, lawful representatives and medical representatives) may be considered as a civil judicial act, since the parties agree to the terms that the first party (medical practitioner) will provide a certain service, whereas the second and the third party (minor patient, lawful representatives) agree to receive such service. Naturally, a minor patient is not always entitled to decide on participation in treatment due to one's special status, but, considering specifics of international law and politics and based on the basic principles of protection of the rights of minor patients, which are based on the principles of fundamental rights of the children, a minor patient definitely is a subject the rights of whom may not be completely restricted. Therefore, a minor patient may be considered as the third party under the context of specified civil judicial relations.

Section 1405 of the Civil Law specifies that in order for a transaction to have legal force, it is necessary that the parties to the transaction have legal capacity and the capacity to act for making such transaction ${ }^{52}$. It follows that under the context of the Civil Law the capacity of a minor person is more oriented towards performing actions which are related to acquiring material gains, for example, concluding transactions. Health and life of any person, including a minor person, is a fundamental right which is invaluable. A minor patient is not fully responsible for this valuable fundamental right; this responsibility lies with

50 30.12.2009. Law on the Rights of Patients. Latvijas Vēstnesis, Nr. 205 (4191)

51 30.12.2009. Law on the Rights of Patients. Latvijas Vēstnesis, Nr. 205 (4191)

52 20.02.1937. Civil Law. Law of the Republic of Latvia. Valdības Vèstnesis, 41, 
the lawful representatives. However, it must be admitted that the legislation of the Republic of Latvia has granted a minor patient more rights in the healthcare field than upon concluding transactions of civil nature.

It follows that legal enactments contain series of faults in regard to the activities of lawful representatives of a minor patient and their involvement in healthcare processes. One of the most significant problems is the question which of the lawful representatives and in what way is entitled to give consent for treatment of the patient who has not yet reached the age of 14 years.

The requirements for lawful representatives to give consent for the treatment of the patient who has not yet reached the age of 14 years, specified in Paragraph 1 of Section 13 of the Law on the Rights of Patients, are not complete and justified. In practice the mentioned legal norm may not be applied due to contradictions of several legal norms. It causes misunderstanding of actions both among medical practitioners and patients and their representatives, since actions of a medical practitioner regarding the requirements specified in this norm, are not stipulated.

Additional misunderstanding is caused by Paragraph 1 of Section 14 of the Law on the Rights of Patients, which stipulates that if the lawful representative of a minor patient refuses to give his or her consent for the commencement of medical treatment or if the lawful representative is unable to agree regarding the commencement of medical treatment, the matter on the treatment of a minor patient may be decided by the Orphan's Court ${ }^{53}$. This section contains a phrase "lawful representatives are unable to agree". Thus, it is indicated that consent for treatment must be given by one of the lawful representatives, but both must agree on this decision. At the same time, it is not clear whether Section 14 is attributed generally to lawful representatives who

${ }^{53}$ 30.12.2009. Law on the Rights of Patients. Latvijas Vēstnesis, No 205 (4191) 
decide on treatment of minor patients, or to lawful representatives of patients who have reached the age of 14 years.

There are also ambiguous cases when one of the lawful representatives has given consent for the commencement of treatment of a minor patient who has not reached the age of 14 years, but the lawful representative is outside the territory of Latvia, or the parents live separately but shared custody is continued. In such case, the lawful representative whose opinion was not taken into account or who was not informed of the relevant situation within the framework of Paragraph 1 of Section 13 of the Law on the Rights of Patients may address the court to protect his/her interests, but primarily the interests of the minor patient. The court, upon adjudicating the case, will rely on the principle of ensuring best interests of the child to prevent a situation when decision of one lawful representative may endanger the life and health of the child.

If a medical practitioner encounters a situation where one lawful representative of a minor patient has consented to commence treatment but the other has not, the medical practitioner shall act within the framework of Paragraph 1 of Section 14 of the Law on the Rights of Patients, namely, address the Orphan's Court with a request to give consent for the treatment of the patient who has not reached the age of 14 years. Ignoring the opinion of the other lawful representative violate his/her rights as the lawful representative, which have been granted to him/her by the Civil Law, the Law on the Protection of the Children's Rights $^{54}$ and other national and international legal enactments.

Since until a patient reaches the age of 18 , it is generally accepted that custody of both parents is established, both lawful representatives shall be jointly and severally responsible for a minor patient under the age of 14 and his/her health.

\footnotetext{
54 04.08.1998. Law on the Protection of the Children's Rights. Latvijas Véstnesis, No 199/200 (1260/1261), 08.07.1998, Ziṇotājs, No 15, Para 1 of Section 5.
} 
Both Latvian and ECHR judicial practices recognise the autonomy of interests of natural guardians. This autonomy manifests as implementation of "natural rights" of parents, including healthcare. As a result, parental autonomy, upon making decisions on the health of minor patients, may cause not only positive but also negative consequences. This is not always implemented on purpose, but often due to such reasons as ignorance or religious aspects. However, in rare cases such behaviour of parents is deliberate and oriented toward endangering the health and life of a child. The rights of both natural guardians are unique and autonomous. Such autonomous rights are also restricted; however, this limitation is directed solely at the protection of the rights of minor patients ${ }^{55}$. Shared autonomous rights of natural guardians historically were protected since ancient times, upon emerging of a family institute, which was described in more detail in the first chapter of the study.

Therefore, provisions of the Law on the Rights of Patients regarding the right of one lawful representative to decide on the health of the child are incorrect and ungrounded, contradict the Civil Law, since they restrict the exclusive rights of other lawful representative to participate in matters which are related to the health of the child. Nevertheless, actions of medical practitioners under the context of the mentioned issues may become difficult, since the complicated question of informing both lawful representatives may turn out to be a problem.

In addition, it should be noted that Paragraph 1 of Section 13 of the Law on the Rights of Patients restricts the rights of a minor patient to decide on his/her own health but gives the rights to be heard and to participate in treatment not as decision maker, but informatively, by expressing his/her opinion. In order to ensure fundamental rights of this patient, which have already been in the study

\footnotetext{
55 Townsend, D. E. Judicial limitations on parental autonomy in the medical treatment of minors: Custody of a minor, Mass, 379 N.E.2d 1053 (1978), aff'd on rehearing, Mass, 393 N.E.2d 836 (1979), Neb. L. Rev., 1980, Vol 59, No 4, p 1110. Available: https://digitalcommons.unl.edu/nLV/vol59/iss4/7 [accessed on 09.07.2018].
} 
before, a medical practitioner should receive the consent from the minor patient as well, regardless of his/her age. Upon performing the evaluation of maturity described above, there is a chance that the opinion of a 13-year old patient may be objective and noteworthy and may affect the results of the process.

A medical practitioner shall rely and consider the opinion of the lawful representatives, which in the given case is complete and is not restricted by the obligation to take into account the opinion of a minor patient. Accordingly, the question is whether the consent for the treatment of the patient below the age of 14 years shall be given by one or two lawful representatives. If both lawful representatives may agree on treatment, there is no problem. The problems may arise in case if parents, who share custody, cannot agree between themselves upon representing the treatment of the patient below the age of 14 years. The legal norm does not stipulate actions to be taken by medical representatives within the framework of this section. 


\section{CHARACTERISTICS OF THE RIGHTS OF MEDICAL PRACTITIONERS IN TREATMENT OF MINOR PATIENTS, PROBLEMS AND SOLUTIONS THEREOF}

Reasons for problems, resulting from legal relations of minor patients and medical practitioners, lie not only with the faults in the legal framework of the rights and obligations of minor patients, but also with the legal framework of medical practitioners. Nowadays the institute of the rights of medical practitioners is not so widely developed as the institute of the rights of patients. Protection of the rights of medical practitioners is directly subject to implementation of the rights of patients. Interaction or legal cooperation of medical practitioners and minor patients has been studied rather little from the scientific perspective. Despite several aspects - introduction of new Internet era in relations of doctors and patients (easier access to information), establishment of judicial practice in the sphere of protection of the rights of patients, development of medical technologies etc., the institute of the protection of the rights of medical practitioners in Latvia has not been sufficiently developed ${ }^{56}$.

Main conditions of interaction of medical practitioners and minor patients are defined both in the Medical Treatment Law and the Law on the Rights of Patients, etc. However, it must be noted that the main feature of these relations is that within such framework medical practitioners mainly have prohibitions and restrictions, whereas minor patients mostly have their rights stipulated.

Medical practitioners are a specific group of professionals, which is characterised by different qualifications (in relation to other persons working in healthcare) and teleological differences (in relation to representatives of other

\footnotetext{
${ }^{56}$ Freckelton, I. Medico-legal ramifications of the evolving doctor-patient relationship. Medicine and Law. World Association for Medical Law Med Law, 2018, Vol 37, No 1, p. 61-86. Available:http://wafml.memberlodge.org/resources/Documents/WAML\%20 Journal\%20Volume\%2037\%20Number\%201.pdf [accessed on 07.11.2018].
} 
professions). Activities of medical practitioners are related to high mental and physical load, social responsibility, high scope of knowledge and application thereof, and assuming of risks. Medical practitioners perform their obligations and professional functions regardless of the place and time, and the work results entail social effect which not only the lives of people depend on, but also the stability of the society in general. This indicates the special value of this profession under the social context not only today, but also in ancient history. Activities of doctors at scientific level started to appear in the $5^{\text {th }}$ century BC when first medical terminology was developed ${ }^{57}$.

Analysis of legal acts allowed establishing that the rights and obligations of minor patients, as well as the rights and obligations of their lawful representatives regarding medical practitioners, have been assigned a much greater significance than the rights of medical practitioners in relations with minor patients and the rights in general. For instance, in the main law of medical practitioners - the Medical Treatment Law the rights of medical practitioners considering patients (without defining minor patients individually) are clearly mentioned in four legal norms. The Medical Treatment Law does not stipulate the rights of a medical practitioner to defend his honour. The rights to honour and dignity have been established both in the Constitution of the Republic of Latvia $^{58}$, also international law, for example, the Universal Declaration of Human Rights ${ }^{59}$; these are not stipulated in the Medical Treatment Law, although disclaimer thereof would serve as legally informative support for the protection of the rights of medical practitioners.

${ }^{57}$ Hippocratic articles. Selection. Translation by Agnese Gaile and Aija van Hofa from from ancient Greek, introduction and comments. Riga: Liepnieks \& Rītups, 2003, xiv.

58 01.07.1993. Constitution of the Republic of Latvia: Law of the Republic of Latvia: adopted at the Constitutional Assembly on February 15, 1992 and comes into force on November 7, 1992. Latvijas Vēstnesis, No 43, Section 95

59 United Nations Universal Declaration of Human Rights. Article 12. Available: http://www.tiesibsargs.lv/lv/pages/tiesibu-akti/ano-dokumenti/ano-visparejacilvektiesibu-deklaracija [accessed on 16.12. 2018]. 
Regarding the rights of minor patients, the obligations of medical practitioners have been stipulated in more than eight legal norms in the Law on the Rights of Patients.

Rights and obligations of medical practitioners are not specified in the Law on the Rights of Patients in a clear and unambiguous manner; they mostly stem from the rights and obligations of patients. Such form of providing information in the legal enactment is intransparent and inefficient, as it is oriented toward only one group of people -patients. At the same time, identifying the rights and obligations of medical practitioners raises a lot of questions regarding their feasibility, for example, the mechanism of determining the maturity degree, receiving of informed consent in writing from a minor person, etc.

Considering the EU practice, rights of medical practitioners are represented by professional associations and unions. Pursuant to Article 2 of the Statutes of the Latvian Medical Association, the aim of the Association is to defend professional, economic and legal interests of doctors ${ }^{60}$. Therefore, on the one hand the rights of medical practitioners are protected at the level of associations, but this mechanism of protection is incomplete, since, for example, conclusions of these organisations are not legally binding, upon adjudication of cases at court, and they have a consultative nature in development of policy planning documents, etc. This also indicates the social status of medical practitioners in Latvia.

Reviewing the institute of rights and obligations of medical practitioners in relation to compliance with the rights and obligations of minor patients allows concluding that the rights of minor patients are superior to the rights and obligations of medical practitioners. It is necessary to strengthen the legal status

${ }^{60}$ Statutes of the Latvian Medical Association. Website of Latvian Medical Association, 12.03.1993. Available: http://www.arstubiedriba.lv/statuti/ [accessed on 21.11.2018]. 
of medical practitioners in relations with minor patients by improving the existing laws and supplementing these with a wider range of rights of medical practitioners. The rights of medical practitioners are not defined specifically and unambiguously within the framework of currently applicable laws and regulations.

In recent years the question about legal awareness of medical practitioners has become more topical ${ }^{61}$.

The information at disposal of rights of medical practitioners is a precondition for provision of quality service. As it was mentioned before, the concept of information is rather wide. Acquiring legal information or legal awareness of medical practitioners is an important aspect within the framework of the study.

Legal awareness is acquisition of information, stipulated in legal enactments in the compliance with requirements specified therein and mastering of relevant knowledge, as well as application and forwarding thereof. Essence of legal awareness is not only the obligation to know and comply with requirements specified in the laws and regulations, but also to apply the acquired information to improve activities of the specific field. Namely, legal awareness of medical practitioners means obligation of medical practitioners to constantly encourage their continued education as professionals with the purpose of improving knowledge in the field of law. Cooperation of medical practitioners and minor patients is based not only on the body of medical documents and regulatory enactments, but also regulatory enactments, which determine the rights and obligations of parties, including those which protect the fundamental rights of minor patients, for example, rights to health and life. Not only the treatment process itself but also the quality and compliance of the rights of persons

${ }^{61}$ Statutes of the Latvian Medical Association. Website of Latvian Medical Association, 12.03.1993. Available: http://www.arstubiedriba.lv/statuti/ [accessed on 21.11.2018]. 
involved in this process depend on the level of legal awareness of medical practitioners.

Pursuant to the Cabinet Regulations No 268 "Regulations on the competence of medical practitioners and students who acquire the first or second level professional higher medical education programmes in medical treatment and their theoretical and practical knowledge" of March 24, $2009^{62}$ in order to perform treatment activities, among other things, a medical practitioner or a doctor must acquire theoretical information on such matters as, for example, legal grounds of professional activity.

It follows from above that any medical practitioner is informed of the legal aspects of treatment regarding the treatment of minor patients. The role of legal awareness in relations of medical practitioners and minor patients is an important precondition not only for the purpose of providing quality service for treatment, but also a matter of ensuring fundamental rights and basic principles of a minor patient.

Cabinet Regulations No 268 stipulate mandatory requirement for a medical practitioner to acquire theoretical knowledge on such matters as, for instance, legal bases of professional activities ${ }^{63}$. Accordingly, it may be resumed that, for example, students of medical professions are given the opportunity to acquire information on legal enactments that regulate their professional activity. Yet, it is not clear from the Cabinet Regulations No 268 whether the rights of minor patients, including the rights of the patient shall be included in this programme. By analysing the content of the mentioned Cabinet Regulations, it

62 16.04.2009.Regulations on the competence of medical practitioners and students who acquire the first or second level professional higher medical education programmes in medical treatment and their theoretical and practical knowledge. Cabinet Regulations No 268 of March 24, 2009. Latvijas Vēstnesis, No 58, Subclause 10.58,

63 16.04.2009. Regulations on the competence of medical practitioners and students who acquire the first or second level professional higher medical education programmes in medical treatment and their theoretical and practical knowledge. Cabinet Regulations No 268 of March 24, 2009. Latvijas Vēstnesis, No 58, Subclause 10.58 
can be concluded that they stipulate that medical practitioners and students who are studying in first or second level professional higher medical education programmes should acquire legal bases of the professional activity. At the same time these regulations do not specify what is meant by "legal bases of the professional activity", and what is included in the scope of knowledge to be acquired. It is essential that the reference to the necessity to ensure rights and confidentiality of patients, included in the Cabinet Regulations, is only attributed to masseurs ${ }^{64}$. Whereas in other Cabinet Regulations, the competence of medical practitioners includes only and solely theoretical knowledge and practical skills in matters related to legal bases of professional activities. It clearly follows from this that a medical practitioner has to have knowledge on the matters of rights of patients.

Upon acquiring rights of patients under the context of these regulations, the programme should also include the rights of minor patients, which would be an integral part of the content of rights of patients.

Information on the rights of minor patients should be acquired in depth upon acquiring professions of such specialities and sub-specialities which require mandatory contact with children, for example, paediatricians, neonatologists, child surgeons, etc.

What happens after acquiring qualification of a doctor is important too. Pursuant to Article 52 of the Cabinet Regulations No 943 "Procedures for Certification of Medical Practitioners" a medical practitioner shall obtain further education points in the primary speciality, of which "at least $60 \%$ are acquired for professional and scientific activity and further education activities, which refer to the professional activity in the primary speciality, sub-speciality,

${ }^{64}$ 16.04.2009. Regulations on the competence of medical practitioners and students who acquire the first or second level professional higher medical education programmes in medical treatment and their theoretical and practical knowledge. Cabinet Regulations No 268 of March 24, 2009. Latvijas Vēstnesis, No 58, 582.4. 
additional speciality, or medical treatment or diagnostic method (for professional and scientific activity and further education activity)" ${ }^{\prime 65}$. The relevant legal norm also includes reference to Annex 5 of these regulations, which stipulates mandatory formal and informal further education activities of professional qualification. If a medical practitioner has participated in professional and scientific activity and further education activity, which is not included in Annex 5 of these regulations, the rights to count these shall be delegated to a certification commission, which evaluates the significance of the given activity and quantity of further education points shall be determined, based on the principle of aligning the listed activities ${ }^{66}$.

Thus, during the recertification a medical practitioner shall not be obligated to participate in such further education activities, where one would have the opportunity to acquire theoretical knowledge on such matters as legal bases of professional activity.

In order to encourage improvement of legal awareness of medical practitioners, a series of practical measures should be undertaken, including solving problems at state, municipal and non-governmental organisation (for example, Latvian Medical Association, etc.) level, paying special attention to education system, further education mechanism and including relevant topics on the rights of minor patients in the agenda of non-governmental organisations, trainings, conferences, seminars, etc..

Communication plays a significant role in relations between a medical practitioner and a minor patient, as well as listening to the opinion of the minor

${ }^{65}$ 02.01.2013. Procedures for Certification of Medical Practitioners. Cabinet Regulations No 943 of December 18, 2012. Latvijas Vēstnesis, No 1 (4807), Article 52, 66 02.01.2013. Procedures for Certification of Medical Practitioners. Cabinet Regulations No 943 of December 18, 2012. Latvijas Vēstnesis, No 1 (4807), Article 52. 
patient in the process of adopting decision, related to health of this patient ${ }^{67}$. This, no doubt, results from legal awareness of medical practitioners.

Uncertainties in application of relevant legal norms, encountered in practice, cause doubts of their quality and conformity to the actual situation. The obligation of a medical practitioner to act, specified in Section 13 and 14 of the Law on the Rights of Patients may be assessed from the aspect of doctor's professional freedom. Professional freedom of medical practitioner in Latvia has been directly embedded in the Medical Treatment Law; therefore, a medical practitioner should feel free upon performance of their obligations and imposed functions in relations with minor patients. However, upon reviewing the expression of the mentioned freedom under the context of Section 13 of the Law on the Rights of Patients, it should be noted that a medical practitioner is not entitled to act freely in regard to the treatment of a minor patient below the age of 14 years and starting from the age of 14 years. Even though a medical practitioner has been granted ethic, moral and professional rights to perform activities related to improvement of health condition for minor patient, these are not absolute. The expression of professional freedom of medical practitioners regarding the treatment of a minor patient coexists with the human rights of this patient as well as the rights of the lawful representatives to decide, for example, on the treatment of a patient below the age of 14 years. Simultaneously, considering the general legal norm of the Law on the Rights of Patients regarding the rights of patients, including minor patients, to refuse the treatment method proposed by a medical practitioner, it indicates poor existence of the mechanism of professional freedom of a medical practitioner at national level ${ }^{68}$.

67 30.12.2009. Law on the Rights of Patients. Law of the Republic of Latvia. Latvijas Vēstnesis, No 205 (4191), Section 13.

68 30.12.2009. Law on the Rights of Patients. Law of the Republic of Latvia. Latvijas Vēstnesis, No 205 (4191), Section 6 
In addition, professional freedom of a medical practitioner is restricted regarding one's obligation to protect health of a minor patient. The regulations of the Law on the Rights of Patients entitle the lawful representatives or the Orphan's Court to decide on the treatment of this patient ${ }^{69}$. The law does not grant a medical practitioner absolute rights to decide on commencement of treatment of the minor patient, but rather offers to extend the procedure of relevant decision making by involving third parties. In this regard, it is essential to note the role of the World Medical Association. The Latvian Medical Association is one of the members of the mentioned association ${ }^{70}$.

Reasonable development of the institute of professional freedom of medical practitioners would strengthen the protection of the rights of minor patients in accordance with the principles of rights of these patients. At the same time cases should be noted, when the lawful representatives of a minor patient refuse from treatment of this patient, acting in interests of the child, and such refusal has lethal consequences. Vaccination of minor patients and refusal of their lawful representatives to have this vaccination done should be noted by analogy as well. In such case, health interests of society are opposed to the interests of a minor patient and the lawful representatives. A solution could be found by developing the professional activity freedom of doctors and reducing the range of rights of the lawful representatives of minor patients. Unequal level of knowledge of medical practitioners and minor patients, as well as special protection of the rights of minor patients reduces theory of duty of trust, thus reducing also the implementation of professional freedom of medical practitioners between the rights of minor patients and medical practitioners.

\footnotetext{
${ }^{69} \mathrm{Ibid}$, Section 13 and 14.

70 World Medical Association. Members. Available: https://www.wma.net/who-weare/members/members-list-printable/ [accessed on 09.12.2018].
} 


\section{LEGAL CHARACTERISTICS AND PROCEDURAL SOLUTIONS RELATED TO DISPUTES BETWEEN MINOR PATIENTS AND MEDICAL PRACTITIONERS}

Legal relations of minor patients and medical practitioners among other things are constituted by a body of legal enactments and framework of relations included therein. Faults of the said framework and the resulting problems cause procedural difficulties in relations of both parties. Therefore, this chapter will examine the characteristics of legal nature and their possible solutions.

Rights, obligations and basic principles of minor patients should be known not only to the subject of protection of children's rights, which are, for example, parents of the child and healthcare institutions ${ }^{71}$, but also to medical practitioners. Failure to ensure the rights of minor patients is based on the level and scope of knowledge, which a medical practitioner has gained upon acquiring certain qualification. Medical practitioners, upon acquiring document confirming the education of the doctor and acquiring certain knowledge and skills, should ensure ideological grounds for society and ensuring of those ethical norms which ensure the rights of society to a qualified and qualitative treatment and healthcare in general ${ }^{72}$. It can be concluded from above that the scope of knowledge and skill will directly affect legal relations of a medical practitioner and a minor patient upon provision of healthcare services.

The institute of professional responsibility of a medical practitioner and its effect on cooperation with minor patients should be specified in the given case. Considering the special status of a minor patient in treatment, the institute

\footnotetext{
71 04.08.1998. Law on the Protection of the Children's Rights. Latvijas Véstnesis, No 199/200 (1260/1261), 08.07.1998, Ziņotājs, No 15

72 Imran, M., Samad, S., Maaz, M., Qadeer, A., Najmi, AK., Aqil, M. Hippocratic oath and conversion of ethico-regulatory aspects onto doctors as a physician, private individual and a clinical investigator. J Midlife Health, 2013, Vol 4, No 4, p. 203-209.
} 
of professional responsibility of medical practitioner under the context of minor patients also should be given adequate attention. Disputes resulting from relations of medical practitioners and minor patients have various characteristics, including procedural and informative - legal ones.

Protection of the rights of patients, including minor patients, is a priority and critical issue, judging from the perspective of international scale. The problems with resolution of disputes related to the harm, which has been caused to the patient, especially a minor patient, are just as important ${ }^{73}$. One of crucial elements in healthcare system in the EU is the level of satisfaction of patients and individual groups of patients with the received healthcare service. This concerns also the protection of the rights of minor patients in regard to receiving quality service from medical practitioners ${ }^{74}$. The quality criterion in relations between a minor patient and a medical practitioner is the most decisive factor for elimination of potential disputes.

In addition to the implementation of relations of minor patients and medical practitioners, upon occurrence of certain conditions, third parties become involved in this, authorised to represent and protect the rights and interests of these patients in the processes related to treatment. The institute of Orphan's Courts is one such element.

Activities of the Orphan's Court are regulated by the Law on Orphan's Courts, which among other things also determines that the Orphan's Court is a guardianship and trusteeship institution established by a municipality or city

73 Slawomirski, L., Auraaen, A., Klazinga, N. The economics of patient safety. Strenghtening a value-based approach to reducing patient harm at national level. OECD, 2017, Grant N.DI161105. Available: https://www.bundesgesundheitsministerium.de/ fileadmin/Dateien/3_Downloads/P/Patientensicherheit/The_Economics_of_patient_safet y_Web.pdf [accessed on 10.01.2019].

${ }^{74}$ Charles, D., Shaw, Kalo I. A background for national quality policies in health systems. World Health Organisation, 2012. Available: http://apps.who.int/iris/bitstream/handle/ 10665/107458/E77983.pdf?sequence=107.07.2006. \&isAllowed=y [accessed on 10.01.2019]. 
local government ${ }^{75}$. Pursuant to this law, the institution shall ensure by priority the protection of the rights and legal interests of a child or a person under trusteeship; therefore, also the interests of a minor patient ${ }^{76}$. Simultaneously, the Orphan's Court shall repose on laws and regulations and principles of the public law in the operation thereof ${ }^{77}$. The main purpose of the Administrative Procedure Law should be noted here, which is closely related to the essence of activity of the Orphan's Court, namely, to ensure compliance with the human rights in public legal relations between the state and an individual ${ }^{78}$. The principles of administrative procedure, specified in the law, which concern the activity of the Orphan's Court, also follow from this ${ }^{79}$.

Additionally, the Orphan's Court in its operation shall perform such obligations as defending personal and property interests and rights of a child or a person under trusteeship, provide assistance to a child or a person under trusteeship, which has requested assistance from an Orphan's Court, represent the personal and material interests and rights of a child during validity of a sole decision, and also cooperate with, for example, healthcare institutions to ensure protection of the interests of a child ${ }^{80}$. Therefore, the priority of the protection of the rights of children, also minor patients, by analogy, is reinforced, in particular, by indirectly emphasising such principles of protection of the rights of minor patients as principle of provision of interests and principle of ensuring special protection.

${ }^{75}$ Law on Orphan's Courts: Law of the Republic of Latvia. Latvijas Vēstnesis, No 107, Section 2

${ }^{76}$ Law on Orphan's Courts: Law of the Republic of Latvia. Latvijas Vēstnesis, No 107, Section 2 Section 4.

${ }^{77}$ Law on Orphan's Courts: Law of the Republic of Latvia. Latvijas Vēstnesis, No 107, Section 2 Section 4.

78 14.11.2001. Administrative Procedure Law. Law of the Republic of Latvia. Latvijas Vèstnesis, No 164 (2551), Section 2

${ }^{79}$ Ibid, Para 1 of Section 4.

${ }^{80}$ 07.07.2006. Law on Orphan's Courts: Law of the Republic of Latvia. Latvijas Véstnesis, No 107 , Article $1,4,7$, and $10^{1}$ of Section 17 
It follows that the general obligations of the institution, specified above, give vast possibilities in protecting the rights and interests of minor patients in the treatment process and related issues. At the same time, special attention should be paid to one of the significant stages of activity of the Orphan's Court, which concerns the activity of the institution in regard to ensuring the rights of minor patients in the treatment process. The Law on Orphan's Courts stipulates the rights of the Orphan's Courts to bring a statement of claim to a court and applications within interests of a child or a person under trusteeship ${ }^{81}$. This essentially allows the Orphan's Courts to represent a minor patient in relation to protection of the rights and interests involved in the treatment process.

Upon reviewing the structure of the Law on Orphan's Courts and the scope of the rights and obligations, it can be concluded that authorisations of the Orphan's Courts are extensive enough and mechanisms integrated in the legal enactment provide the opportunity to protect the rights and interests of minor patients, based on the initiative of the institution and also on the initiative of the minor patient.

Despite the system of protection of the rights and interests of the children stipulated in the Law on Orphan's Court, it is important to pay attention to the framework of the Law on the Rights of Patients, which launches the model that allows viewing the scope of rights and freedoms of minor patients from the perspective of the field of work of Orphan's Courts. The Law on the Rights of Patients stipulates a system, which includes specific actions to be taken both by a medical practitioner and the lawful representatives of a minor patient to apply the Law on Orphan's Court ${ }^{82}$.

${ }^{81}$ 07.07.2006. Law on Orphan's Court: Law of the Republic of Latvia. Latvijas Vēstnesis, No 107, Para 5 of Section.

82 30.12.2009. Law on the Rights of Patients: Law of the Republic of Latvia. Latvijas Vēstnesis, No 205 (4191), Section 14 
By analysing the regulations of Section 14 of the Law on the Rights of Patients regarding the capacity of the Orphan's Court to protect the rights and obligations of minor patients, a question arises of the way how patients are heard and to what extent their interests are taken into account. Section 14 of the Law grants extensive powers to a medical practitioner to represent the rights and interests of a minor patient, and, unlike Section 13, does not stipulate the rights of a minor patient to receive information that is understandable according to the age and maturity of the patient or to be heard and to participate in the adoption of decisions, related to the treatment, according to his or her age, in the new stage, which is commenced within the framework of Section $14^{83}$.

Therefore, the role of the Orphan's Courts in the treatment process of minor patients largely depends on activities and ability of a medical practitioner to implement the rights granted to him or her within the framework of Section 14 of the Law on the Rights of Patients. The Law determines rather short terms for provision of answers and making of decisions of the Orphan's Courts for a medical practitioner ${ }^{84}$. But there is an important question about how often medical practitioners choose to enforce the rights granted to them and how often proactive actions result in preparing of necessary documents for the Orphan's Courts to make decisions related to the treatment of minor patients.

If one of the mechanisms of protection of the rights of minor patients is Orphan's Courts, the next one is related to the alternative resolution method of disputes between minor patients and medical practitioners.

When analysing the alternative options for dispute resolution in healthcare system between minor patients and medical practitioners, it is important to understand that all kinds of these disputes are social disputes and

83 30.12.2009. Law on the Rights of Patients: Law of the Republic of Latvia. Latvijas Vēstnesis, No 205 (4191), Section 13 and 14

84 30.12.2009. Law on the Rights of Patients: Law of the Republic of Latvia. Latvijas Vēstnesis, No 205 (4191), Section 14, Para 1 and 2. 
they should be considered from the perspective of social rights. Especially if one party of the potential dispute is a minor person with certain legal restrictions of action and freedoms.

Disputes between minor patients and medical practitioners are emotional, which may, however, be prevented outside the court, namely, at the level of mutual communication. Special attention shall be paid to neutralising destructive emotions and clarifying the real reasons of the conflict ${ }^{85}$.

One way to resolve such disputes is a mediation process, which, based on the Directive 2008/52/EC of the European Parliament and of the Council of 21 May 2008 on certain aspects of mediation in civil and commercial matters, was implemented in legislation of the Republic of Latvia. The Mediation Law adopted in 2014 and, therefore, the legal framework of the Republic of Latvia has enabled to apply alternative method for dispute resolution - the mediation, including in healthcare disputes ${ }^{86}$. However, a separation must be made between mediation in civil matters, criminal matters and administrative process from the mediation recommended by the court. The mediation recommended by the court will not be considered in detail further in this study.

Section 1 of the Mediation Law clearly defines that mediation is a structured co-operation process on voluntary basis whereby the parties attempt to reach a mutually acceptable agreement on the settlement of their dispute. The process is managed by a mediator. At the same time Paragraph 2 of Section 2 of the Mediation Law stipulates that mediation may be used for settlement of

${ }^{85}$ Trosens A., Hofmans R., Rotfišere Dorisa B. Mediācija. Mediācijas pamati teorijā un praksē (Eng. Mediation. Basics of mediation in theory and practice). VAS "Tiesu namu aǵentūra", 2007, p. 136-140.

86 18.06.2014. Mediation Law: Law of the Republic of Latvia. Latvijas Vēstnesis, No 108 (5168) 
disputes in pre-trial proceedings, as well as in judicial proceedings, if not provided for otherwise in special legal norms ${ }^{87}$.

Section 23 of the Civil Procedure Law stipulates that all civil disputes shall be subject to court ${ }^{88}$. This does not deprive the parties of the rights to agree on dispute settlement via mediation. This means that the legal framework has settled the normative base, giving way to alternative dispute resolution models also in disputes between patients and medical practitioners or medical institutions ${ }^{89}$.

Section 18 of the Law on the Rights of Patients specifies the way in which a person, including a minor patient, may protect its lawful rights and interests, stating that: "A person may use all mechanisms for the protection of rights provided for in laws for the protection of the rights or the interests arising therefrom laid down in this Law, including application to a court in accordance with the procedures laid down in law." ${ }^{90}$. The words "use all mechanisms for the protection of rights provided for in law" indicate also the possibility of applying mediation process. However, the law does not contain specific references to the possibility of using mediation. Since mediation process is not extensively used in Latvia, promoting it at different levels, including in the content of legal enactment, would encourage its application.

Application of mediation in healthcare could serve not only as a mechanism for resolution of disputes at the out-of-court stage, but also would help identifying on-time systemic errors and faults, which occur in the healthcare

87 18.06.2014. Mediation Law: Law of the Republic of Latvia. Latvijas Vēstnesis, No 108 (5168)

${ }^{88}$ 20.02.1937. Civil Law. Law of the Republic of Latvia. Valdības Vēstnesis, No 41

${ }^{89}$ Palkova, K. Possibilities for application of mediation in healthcare field, Collection of electronic scientific articles of the Faculty of Law of RSU SOCRATES, 2015, No 3 (3), p. 5 .

90 30.12.2009. Law on the Rights of Patients. Law of the Republic of Latvia. Latvijas Vèstnesis, No 205 (4191), Section 18 
field as a result of legal communication of patients and medical practitioners. In the United States, mediation is widely used in healthcare field ${ }^{91}$.

Mediation is widely used in healthcare disputes in several EU countries. In countries such as France, Estonia, Luxembourg, Malta, Slovenia, Spain, etc. mediation is used to resolve disputes, where, for instance, both the rights of a patient and a medical practitioner have been infringed ${ }^{92}$. Such form of mediation in the mentioned countries may also be recommended by the court. In Latvia use of mediation in healthcare disputes between minor patients and medical practitioners is not popular.

It should be noted that mediation process offers individual approach to resolution of medical conflict. Mediation in healthcare disputes might not only unburden the work of the court, the Health Inspectorate, etc., but also become the mechanism of conflict resolution, often used in out-of-court situations ${ }^{93}$.

By applying mediation in healthcare disputes, the problems, which the parties may encounter by choosing this process, must be identified. For example, the problems of procedural nature, related to the special status of a minor patient, identification of mediation participants, lack of information necessary for the process, costs, etc.

Regardless of the series of the stated problems, there are certain advantages to application of mediation in the process of healthcare disputes between minor patients and medical practitioners, for example, quick and confidential process, economic side of use of process on the condition that the mediation process is free of charge for the parties (for example, free mediation

${ }^{91}$ Sheea Sybblis. Mediation in the healthcare system: Creative problem solving, 6 Pepp. Disp. Resol. L. J., 2006, No 3. Available: http://digitalcommons.pepperdine.edu/ drlj/vol6/iss $3 / 6$

92 HOPE - European Hospital and Healthcare Federation. 2012. Mediation in Healthcare. Available: https://www.mediate.com/pdf/91_HOPE_Publication-Mediation_December_ 2012.pdf [accessed on 09.12.2018].

93 Hall, M. A., Bobinski, M. A., Orentlicher, D. Medical liability and treatment relationships. $2^{\text {nd }}$ ed. 2008 , p. 433. 
services within the framework of state and municipality financed projects) and a more gentle process in emotional terms.

Currently in Latvia there are no statistics on mediation processes in healthcare. Therefore, there is lack of data to fully study mediation in healthcare disputes between minor patients and medical practitioners. The Mediation Council, the purpose of which, among other things, is to promote development of favourable mediation environment in Latvia ${ }^{94}$, would have to create and maintain record system for mediation cases in healthcare disputes. The author of the Thesis will provide such suggestion to the Mediation Council. Whereas in regard to the information provided by the mediators, who are not members of the Mediation Council, the author of the study will encourage discussions with the management of the leading Latvian associations, for example, the association "Medius", association "Integrated mediation in Latvia", etc., which offer and implement mediation education and continued education programmes.

Majority of the conflicts, especially those related to dissatisfaction of patients with the work of medical practitioners, may be solved by a doctor or the top ranking official of medical institutions at communication level. Having a conversation allows both calming down a patient and finding solution to the situation. Nevertheless, there are situations when the conflict is not resolved between a medical practitioner and a patient. A patient, including a minor patient, his or her lawful representatives, attempting to protect certain rights and interests, filed complaints to a higher-ranking institution or addressed the court. Such medical conflicts are often based on medical errors, dissatisfaction with the quality of the provided medical care, inappropriate communication, etc.

Mediation in healthcare disputes, where one of the parties is a medical practitioner, but the other is a minor patient, is rare in Latvia, but it might exist

\footnotetext{
94 Mediation Council. Current issues. Available: http://www.mediacija.lv/?Medi\% C4\%81cijas_padome [accessed on 14.11.2018].
} 
as an alternative solution to such conflicts. The opportunity to use mediation in healthcare disputes, provided by the legislation, should be implemented at the state, municipal and private sector level, thus creating a new practice for resolution of such complex disputes. 


\section{CONCLUSION}

The objective of the doctoral thesis has been reached. To create scientific research about the problems of the legal relations of minor patients and medical practitioners, provide proposals to improve the legal framework, and to create theoretical basis for improving the legal relations of minor patients and medical practitioners during the medical treatment.

The doctoral thesis provides answers to the research questions in the discussion of the doctoral thesis.

Rapid development of medical law is observed today not only in the world in general, but also in Latvia. Such medical law institutions as European Association of Health Law, World Association for Medical Law and others are established and becoming more active. The number of cases considered by the ECHR in the field of healthcare increases too. As the scope of information regarding legal rights of patients and medical practitioners and the resulting consequences grows, a patient has become a proactive subject. However, it is not only the rights of minor patients that experience a new development stage; the rights of minor patients are a subject to this as well.

The problems of legal relations of minor patients and medical practitioners cause shortcomings in compliance with the rights of the parties and implementation of obligations. Improving relations of the relevant nature will strengthen the rights and obligations of the parties, which essentially depend on the interpretation and application of the existing legal framework. Considering the complex and specially protected status of the rights of minor patients in medical treatment, implementation of their rights depends on other subject, for example, medical practitioners who, among other things, undertake protection of the rights and interests of minor patients in medical treatment. Legal relations of minor patients and medical practitioners are regulated both at international and national level. Yet, the basic principles of minor patients (children), defined by 
international legislation, in healthcare field are not always implemented clearly. As a result, medical practitioners in performance of their main task, upon occurrence of certain situations, face difficulties in interpretation and application of legal norms and problems ensuring the rights of minor patients. This happens due to unclear and incomplete legal framework, as well as common political vision. The study has found answers to the stated research questions. The objective of the work has been achieved, namely, a comprehensive scientific study has been developed on the problems of legal relations of minor patients and medical practitioners, offering proposals for improvement of legal framework.

It follows from the results of the Doctoral Thesis that the legal framework of the institute of rights of minor patients in Latvia is incomplete. Shortcomings identified in the framework cause uncertainties in the activities of medical practitioners as well, upon implementing and protecting the rights of minor patients. Improvements of the legal framework are necessary not only in the legal enactments regulating the general industry, but also in the special legal enactments which directly concern legal relations of the medical practitioners and minor patients. Conclusions have been made within the framework of the Doctoral Thesis and proposals have been given for resolution of the problems resulting from the content of the study and improvement of this field.

The conclusions and proposals identified as a result of the study may be divided into several groups.

1. The first group includes conclusions and proposals, which are based on identification of principles of protection of the rights of minor patients, experience in application thereof and possible improvement of legal enactments. 


\section{Conclusions}

1.1. A minor patient is a child and all principles of protection of the rights of the child are applicable to him or her.

1.2. The national laws and regulation have not identified and enshrined into the law the principles of the legal protection of minor patients from the special status of the minor patient follow, which is based the specifice rights of the minor patient and the specific protection of these rights.

1.3. Upon examining the principles of protection of the children's rights, as well as the scope of the rights and interests of minor patients in the treatment process, four principles were identified within the framework of the study, which can be transformed and applied also under the context of the rights of minor patients: principle of non-discrimination, principle of ensuring of interests, principle of participation and principle of ensuring special protection.

1.4. Upon applying the principle of non-discrimination to mechanisms of protection of the rights of minor patients, comparison of a minor patient and an adult patient under similar conditions leads to a potential violation of the nondiscrimination principle in provision of the healthcare service, by providing the rights for adult persons - lawful representatives of minor patients, medical practitioners or the Orphan's Court to make decisions on the treatment of minor patients in Latvia.

1.5. In situation when a similar healthcare service is received both by an adult patient and a minor patient, the non-discrimination principle is fulfilled by the criterion of age and application and understanding of the principle of rights of minor persons, depending on the applicable sphere.

1.6. The principle of ensuring the best interests of the child must be given priority upon implementing different activities, oriented towards minor patients. The principle of ensuring the best interests of the child is not directly stipulated in the Law on the Rights of Patients but is only partially integrated in individual legal norms. 
1.7. The principle of ensuring best interests of the child under the context of protection of the rights of minor patients determines the obligation of the lawful representatives of the minor patient and also the medical practitioners to hear the opinion and thoughts of this patient and to involve him or her in decisionmaking process, but does not grant the minor patients the rights of adults or complete (unrestricted) rights.

1.8. Legal rights of minor patients and medical practitioners are based on ensuring of the best interests of these patients, which, among other things, is justified by the principles of the rights of minor patients. The concept of best interests of minor patients is very extensive and is not defined in the legislation of Latvia, which results in difficulties in application thereof, especially in healthcare.

In order to ensure development of application of the mentioned principles as well as their practical application in legal relations of medical practitioners and minor patients, the following proposals are put forward.

1.9. To specify Section 3 of the Law of the Rights of Patients by expressing it as follows:

"Section 3. General provisions.

(3) In ensuring the rights of a minor patient to participate in making of the decision related to the treatment and in implementing the rights to protection of lawful interests, the following special principles of protection of the rights of minor patients shall be recognised as the principle of non-discrimination by age, principle of ensuring interests, principle of participation and principle of special protection."

2. The second group includes conclusions and proposals, which concern the special status of a minor patient and characteristics of this status during the treatment process. The following conclusions were made within the framework of the study. 


\section{Conclusions}

2.1. Rights of minor patients have transformed. The stated transformation results in having the rights of minor patients subjected to restrictive activities, as a result of which the capacity of a minor patient has become incomplete; therefore, reducing the scope of legal activities constantly implemented by a relevant person.

2.2. Currently, there is lack of common approach to regulation of the rights of child in various sectors. The national level legal enactments, for example, the Education Law, the Youth Law, the Civil Law, the Criminal Law stipulate conceptually different mechanisms for implementation of the principle of children's participation than in the Law on the Rights of Patient, which provides for participation of children from the age of 14 only. The lack of common approach to legal framework of the rights of children, including minor patients, indicates several legal risks and encourages different and unclear understanding of the industry specialists regarding the participation of minors, especially in cases of relations between minor patients and medical practitioners. Right now the special law - the Law on the Rights of Patients restricts the application of the principles of protection of the rights of the children, specified in the Law on the Protection of Children's Rights in relations between a minor patient and a medical practitioner.

2.3. The concept of a minor person is extensive and allows differentiating age thresholds depending on situations which occur during the process of establishment of legal relations. In determining the rights and obligations, as well as obligations of minor person, the legal framework is not equally defined for children of different age. It specifies increase of responsibility as the minor person reaches a certain age, namely, in adoption matters - 12 years, in healthcare matters - up to 14 years and more than 14 years, upon occurrence of pregnancy - 16 years. Educational means of coercion shall be applied from the age of 11 , whereas participation in civic activities and development of youth 
policy is possible from the age of 13. This causes misunderstanding of equal approach towards determining the mechanism of responsibility of minor patients. The above creates misinterpreation about equal approach to the determination of the responsibility mechanism of minor patients, discrediting the special status of the minor patients and the following privileges.

2.4. In healthcare field, national legal enactments grant minor patient a lot less rights than an adult person upon concluding civil material transactions. The legal enactments entail series of faults regarding the activities and involvement of lawful representatives of a minor patient in healthcare processes, as well as cooperation with a medical practitioner.

2.5. Legal enactments of the Republic of Latvia provide no reference to the definition of the concept of a minor patient; they include the concept of a minor person, but the definition cannot be found in either special literature or legal enactments.

2.6. Legal enactments of the Republic of Latvia lack unified terminology about the term "minor patient". Both the Law on the Rights of Patients and the Medical Treatment Law, the Sexual and Reproductive Health Law use such terms as minor person, minor patient, minor, child. The Law on the Rights of Patients as a special law does not stipulate the term "patients" and "minor patient".

In order to prevent faults related to the special status of minor patient in treatment process, the following proposals are put forward.

2.7. To supplement Section 1 of the Medical Treatment Law with definition of minor patient as follows:

"Section 1. The following terms are used in this Law:

11. ${ }^{\mathbf{1}}$ ) minor patient - person who is reached the age of majority in accordance with the statutory procedure and who receives healthcare services or seeks them, or is involved in a clinical study." 
2.8. To supplement Paragraph 6 and 7 of Section 1 of the Law on the Rights of Patients as follows:

11) patient - a person who receives healthcare services or seeks them, or is involved in a clinical study".

2.9. To Supplement Paragraph 6 and 7 of Section 1 of the Law on the Rights of Patients as follows:

6) patient - a person who receives healthcare services or seeks them, or is involved in a clinical study".

7) minor patient - person who has not reached the age of majority in accordance with the statutory procedure and who receives healthcare services or seeks them, or is involved in a clinical study."

3. The third group includes conclusions and proposals which concern implementation of the rights of minor patient in the treatment process and related problems.

\section{Conclusions}

3.1. The patient who has reached the age of 14 years and is sufficiently mature shall be entitled to refuse treatment even on the condition that the medical practitioner believes that refusal is not in the interests of the patient.

3.2. Section 5 of the Law on the Rights of Patients allows minor patients, regardless of the degree of maturity and without stipulating age thresholds, to refuse treatment and to leave the medical treatment institution, which is not possible under the context of Section 13, since the minor patient is not given such extensive authorities in this Section.

3.3. First sentence of Paragraph 1 of Section 13 of the Law on the Rights of Patients restricts the rights to participation of the patients below the age of 14 . In turn, the second sentence of Paragraph 1 of this Section narrows down the restriction which directly indicates the possibility of application of the principle of equality, at the same time specifying that this principle is not exclusive and 
not absolute. There is lack of common understanding of the application of principle of participation in different industries, including the matter of protection of the rights of minor patients. Various legal enactments demonstrate different approaches to the question of understanding of the participation concept, which may cause difficulties in application of these norms.

3.4. Paragraph 1 of Section 13 of the Law on the Rights of Patients narrows down the rights of a minor patient to participate in the adoption of a decision, related to treatment; the rights of minor patients and the lawful representatives to participate in this process have not been specifically embedded in the law and the model of activity of a medical practitioner in regard to the requirements, specified in this legal norm, has not been precisely stipulated.

3.5. Section 13 of the Law on the Rights of Patients includes restricted rights of a minor person to participate in the processes related to treatment, which essentially contradicts the general norm of the Law on the Rights of Patients, as well as Article 2 of the UN Convention of the Rights of the Child and Article 21 of the Charter of Fundamental Rights. Within the framework of the Law on the Rights of Patients, the principle of non-discrimination is manifested as restriction of the rights of minor patients to participate in treatment process by delegating the aforementioned rights to lawful representatives, medical practitioners or the Orphan's Court, therefore causing advantage of these persons and institutions. The age of the patient which determines the scope of rights and obligations granted to him or her is a sign of discrimination.

3.6. Regulations included in Paragraph 2 of Section 13 of the Law on the Rights of Patients regarding the restricted rights of a minor patient to refuse treatment contradict international legislation, since autonomous rights of minor patients above the age of 14 to decide on their treatment are not complete.

3.7. Rights of the minor patient about the opinion provided by him or her during the treatment process increase with the age, and the maturity of a minor patient increases. This means that the rights of the lawful representatives in this 
field are reduced accordingly. Paragraph 3 of Section 13 of the Law on the Rights of Patients demonstrates discrimination of the rights and interests of minor patients in the question on making of decision in treatment process. The subject of the law has been granted negative rights to making of relevant decision by this legal norm.

3.8. Section 13 of the Law on the Rights of Patients does not define the rights of minor patients to express dissatisfaction, proposals and recommendations on the received services, provided by a medical practitioner. The mechanism in which the opinion may be formed is not defined either. The rights of minor patients to express opinion related to the received healthcare service are incomplete in Latvia. The process in which a minor patient may submit complaint or proposal on the treatment process does not differ from that regulating adults.

In order to strengthen and improve the rights of minor patients in medical treatment process, the following proposals are put forward.

3.9. To supplement Paragraph 1 of Section 13 of the Law on the Rights of Patients as follows:

“(1) Medical treatment of a minor patient (up to the age of 14 years) shall be permissible if the consent of this patient has been received and his or her lawful representative is informed thereof and has given his or her written consent. The minor patient has the right to be heard and according to his or her age and maturity to participate in the making of the decision related to the medical treatment. The consent of the minor patient and the lawful representatives shall be included in medical documents."

3.10. To update Article 10 of the Cabinet Regulations No 265 "Procedures for Keeping Medical Documents” of April 4, 2006 as follows:

"10. The medical entries shall contain information which ensures recognition of a patient, certifies the patient's consent to treatment, certifies diagnosis, 
substantiates examinations and medical treatment methods, and precisely demonstrates medical treatment results."

3.11. To supplement Paragraph 2 of Section 13 of the Law on the Rights of Patients as follows:

“(2) Medical treatment of a minor patient (from the age of 14 years) shall be permissible if his or her written consent has been received, which shall be included in medical documents, except that laid down in Section 7 of this Law."

3.12. To update Paragraph 3 of Section 13 of the Law on the Rights of Patients as follows:

“(3) If a minor patient (from the age of 14 years) makes a decision on the treatment, but the physician believes that this decision is not in the interests of this patient, the consent for the medical treatment shall be given by the lawful representative of the minor patient. The refusal of the minor patient shall be made in writing and attached to the medical documents."

4. The fourth group consists of conclusions and proposals which result from the study of characteristics of the rights and obligations of medical practitioners in the process of implementation of the rights of minor patients in treatment.

\section{Conclusions}

4.1. The rights of medical practitioners are not defined specifically and unambiguously within the framework of currently applicable laws and regulations. These fail to include fundamental rights of medical practitioners, which have been granted to them just as any other citizen, including a minor patient.

4.2. Medical practitioners play a special role in ensuring the best interests of minor patients. Neither a special law, nor other legal enactments have established a clear and unambiguous mechanism that would encourage the action model of medical practitioners in evaluation of best interests of minor patients before making the decision on treatment. No guidelines or recommendations 
have been developed for medical practitioners which would determine methods for evaluation of best interests of minor patients. Failing to consider the best interests of the child or refusing to consider opinions of such child is treated as a significant violation of the rights of a child to health.

4.3. The institute of professional freedom of medical practitioners is closely linked to implementation of the rights of medical practitioners in working with minor patients. The institute of professional freedom of physicians is not absolute and is accordingly restricted by several mechanisms, including legal norms, ethical principles, especially in participating in treatment of a minor patient. The expression of professional freedom of medical practitioners regarding the treatment of a minor patient coexists with the human rights of this patient as well as the rights of the lawful representatives to decide, for example, on the treatment of a patient below the age of 14 years.

4.4. Medical practitioners have the obligation to take into account and evaluate the degree of maturity of a minor patient. The institute of maturity has been defined in both Section 13 of the Law on the Rights of Patients and Section 69.1 of the Medical Treatment Law, and other legal enactments, which stipulate the rights of minor patients.

4.5. Legal enactments do not stipulate a detailed procedure for evaluation of maturity or exact conditions, under which a medical practitioner must perform the mentioned evaluation.

4.6. There is no clear definition of the term "maturity" in Latvia. There is no mechanism that would indicate the use of the institute of maturity among minor patients and medical practitioners. At the same time there is no system which would allow synchronising similar cases both in courts and in medical institutions. There is no clearly defined significance of the degree of maturity in the Medical Law in Latvia, especially in relations which concern interaction of minor patients and medical practitioners during the treatment process. 
4.7. The Orphan's Court has extensive authorities in relations between medical practitioners and minor patients, and mechanisms, integrated in the legal enactments, provide the opportunity to protect the rights and interests of minor patients, based on the initiative of the institution and also on the initiative of a minor patient.

4.8. The role of the Orphan's Courts in the treatment process of minor patients largely depends on activities and ability of medical practitioners to implement the rights granted to him or her within the framework of Section 14 of the Law on the Rights of Patients.

4.9. After proactive activity of medical practitioner in case of activating the mechanism of the Orphan's Court, considering the provisions of Section 14 of the Law on the Rights of Patients, in making decisions on commencement of treatment of a minor patient, the Orphan's Court should also consider interests of a child, paying special attention to the evaluation of maturity of a minor patient.

In order to ensure creation of a legally safer environment for medical practitioners, upon cooperation with minor patients, the following proposals are put forward.

4.10. To carry out medical activity, in accordance to those stated in the regulations, the medical practioner must have theoretical knowledge in such issues as legal bases of professional activity. Pursuant to the level of knowledge of the medical practitioner regards to the protection of rights of the minor patient in the Cabinet Regulations No. 268 of March 24, 2019 "Regulations on the competence of medical practitioners and students, who acquire the first or second level professional higher medical education programmes in medical treatment and their theoretical and practical knowledge", the regulations should provide an requirement that medical practitioners must have theoretical knowledge on the rights of patients. Thereby it is necessary to supplement the regulations 7.1 11, $10.58,16.21,20.29,24.4,28.3,32.12,36.10,104.4,108.13,112.5,116.5 ., 120.5$, 
124.5, 128.15, 132.5, 136.5, 137.3 5, 140.8., 144.24, 148.8, 152.31, 156.22, 160.18, 164.3, 168.3, 172.5, 176.17, 180.11, 184.10, 188.5, 192.8, 196.8, 200.8, 204.14, 208.4, 216.23, 217.3 35, 220.4, 224.14, 225.3 8, 228.20, 232.15, 236.4, 240.5, 244.5, 248.5, 252.13, 256.10, 257.3 5, 260.5, 261, 263.11, 264.8, 268.19, 272.5, 276.3, 280.8, 284.24, 288.20, 292.22, 296.4, 300.3, 304.36, 308.10, 312.9, 316.3, 321.6, 326.3, 331.5, 336.3, 341.7, 346.6, 350.3, 356.34, 361.8, 371.18, 376.4, 381.3, 386.17, 390.26, 401.7, 406.18, 411.5, 412.9 32, 416.11, 421.21, 426.8, 431.8, 440.4, 443.7, 447.4, 451.5, 455.7, 459.4, 463.8, 467.12, 471.5, 468, 479.3, 491.12, 495,10, 498.9, 501.10, 506.20, 511.10, 516.6, 521.16, 526.8, 531.11, 537.9, 543.11, 549.11, 561.16, 566.16, 570.7, 574.14, 583.13, 587.8, 592.7, 597.3, 602.21, 606.23, 610.23, 619.8, 623.15, 628.19, 632.9, 633.3 3, 633.813 , after the words "legal grounds" there shall be inserted words "and the rights of the patients".

Similar updates should be made also to the following articles and subarticles of these provisions: 109, 125, 137, 149, 201.1, 261, 257.7, 265, 269.3, 293, 309.2, 464, 468, 472, 476, 503, 508, 513, 518, 523, 528, 533, 539, 545, 551, $557,563,567,571,575,580,594,603,607,620,625,629,633,633.5$., to supplement the specified scope of knowledge and practical skills with reference to the increase of the level of knowledge not only in the legal basics of professional activities but also in the field of rights of the patients.

4.11. Update Annex 5 of the Cabinet Regulations No 943 "Procedures for Certification of Medical Practitioners" of December 18, 2012, as follows.

"4.Continuing education in congresses, conferences, symposiums, seminars and other events in Latvia, including, legal congresses, symposia conferences, seminars relating to the professional activities of medical practitioners". 
4.12. Supplement Section 48 of the Medical Treatment Law as follows:

"Section 48. A medical practitioner has a duty to regularly improve his or her professional qualifications and become educated in the provision of emergency medical care, as well as the sphere of rights of patients."

4.13. Supplement Paragraph 1 of Section 5 of the Law on the Protection of the Children's Rights as follows:

"19. A medical practitioner, who participates in the treatment of minors", by specifying the numbering of other articles accordingly.

4.14. Supplement sub-article 2.1 of the Cabinet Regulations No 173 "Regulations on the procedure for acquiring special knowledge in the field of the protection of the children's rights, the content and scope of this knowledge" as follows:

"2.1.4. medical practitioners, who participate in the treatment of minors in accordance with the laws and regulations on training of medical practitioners."

4.15. Supplement Article 7 of these Regulations by a new clause as follows:

"7.8. rights of the children in treatment process".

The logically related articles and sub-articles shall be updated accordingly.

4.16. Supplement Section 13 of the Law on the Rights of Patients as follows:

“(5) If a minor patient makes a decision on treatment or provides opinion on making of a decision related to treatment, but the physician believes that this decision or provided opinion is not in the interests of this patient, the physician shall evaluate the age and degree of maturity of the minor patient."

5. The fifth group includes conclusions and proposals, which result from the research of the institute of the rights of minor patients ensuring the rights of participation of these patients in treatment process. 


\section{Conclusions}

5.1. Minor patients as a group of specially protected persons are entitled to special conditions regarding implementation of their rights and freedoms in any sphere, including healthcare, by expressing their opinion or dissatisfaction with the received service. But, despite the stated as well as positive trends in the legal framework in terms of submission of complaints and proposals, the mechanism of implementation of the rights of minor patients is still incomplete. The process, according to which the minor patient may submit a complaint or proposal regarding treatment process, does not differ from that of adults.

5.2. The medical treatment institution and a medical practitioner shall inform minor patients of a mechanism for filing a complaint. Written answers shall be provided to the written complaints or submissions of minor patients. The complaints, submissions and letters, submitted by minor patients shall be registered in the register of submissions of the medical treatment institution, which would prevent ignoring the non-discrimination principle; thus, ensuring equal access to receiving of information, as well as consideration of complaints and submissions on the treatment process.

5.3. Information on the rights of a minor person to express dissatisfaction, to file a complaint or proposal regarding the work of a medical practitioner, or to express a praise, should be available to minor patients, not only their lawful representatives. Such information should be expressed in a language and style understandable to a minor patient, considering the legal characteristics of the status of this patient. The rights of a minor patient to express the opinion on the received healthcare service should be respected; it follows from the basic principles of general rights of minor patients. Primarily performance of these rights depends on a medical practitioner, involved in the treatment of a minor patient. 
5.4. A mechanism for submitting anonymous complaints and submissions to medical practitioners should be provided, which would be friendly to minor patients.

5.5. Under the context of the Cabinet Regulations No 60 "Regulations Regarding Mandatory Requirements for Medical Treatment Institutions and Their Structural Units", of January 20, 2009, no work is being done with a special group of patients - minor patients. The Cabinet Regulations do not specify minor patients as subject of the survey. These regulations do not stipulate a mechanism for surveying minor patients about the quality of healthcare services within the framework of the mentioned regulations.

In order to improve the development of the institute of the rights of participation of minor patients in treatment process, the following proposals are put forward.

5.6. To create within the treatment facilities internal regulations "The procedure of submitting applications, proposals and complaints", which should provide clear and obvious regulations, which would give the minor patients a chance to express their opinion about the treatment process as a whole, as well as the work of the medical practitioners. The document should include reference to a system, which will help to monitor the lawful representatives of minor patients regarding their influence on the participation of the minor patient in decisions taken related to their treatment.

5.7. Supplement sub-articles 17.8 and 17.10 of the Cabinet Regulations No 60 "Regulations Regarding Mandatory Requirements for Medical Treatment Institutions and Their Structural Units", of January 20, 2009 as follows:

"17.8. introduce and maintain the system for analysing the complaints and suggestions of minor patients;

17.10. regularly perform surveys of the patients, including minor patients, regarding the provided healthcare services.". 
6. The sixth group includes conclusions and proposals, which refer to the resolution of the disputes between a medical practitioner and a minor patient in relation to healthcare, to be resolved out of court.

\section{Conclusions}

6.1. In Latvia healthcare-related disputes between medical practitioners and minor patients are mostly resolved in general jurisdiction courts. Section 18 of the Law on the Rights of Patients states that a minor patient may use all mechanisms for protection of rights provided for in laws for the protection of the rights or interests arising therefrom laid down in this Law, including application to a court in accordance with procedures laid down in law. However, the law does not contain specific reference to possibilities of using mediation.

6.2. Application of mediation process in disputes between minor patients (lawful representatives) and medical practitioners may serve as an efficient way of resolving conflicts, but there are series of restricting factors which may make the application of the mentioned process rigid and inefficient.

6.3. There are no statistics in Latvia on mediation processes in healthcare. Therefore, there is lack of data to allow efficient study of mediation in healthcare disputes between minor patients and medical practitioners.

6.4. Promotion and more frequent use of mediation process in healthcare disputes depends on medical institutions and medical practitioners as well, by signing certain contracts with patients and stipulating that mediation process should be used before resolving disputes in general jurisdiction court.

Considering the above and encouraging the development of the application of mediation process in healthcare disputes between medical practitioners and minor patients, the following proposals were developed.

6.5. Supplement Paragraph 1 of Section 18 of the Law on the Rights of Patients as follows:

“(1) A person may use all mechanisms for the protection of rights provided for in laws for protection of the rights or interests arising therefrom laid down in 
this Law, including use of mediation, and also file an application to a court in accordance with the procedures laid down in the law".

6.6. Make the following amendments to the statutes of the Mediation council:

Make these amendments to the paragraph 2.6.11 of the statutes of the Mediation council in as follows:

"2.6.11. to ask and collect information about the practice of certified mediators, as well create and maintain statistical database in mediation cases, including mediation cases in the field of medical rights including information about:

1.1.1.1. the case, specifying the mediator and the involved parties;

1.1.1.2. information on the examination of the mediation process;

1.1.1.3. information about the field of law the mediation process is carried out."

6.7. To advise medical treatment centres to supplement the reference on dispute examination process included in the treatment agreement, including there a paragraph about the use of mediation in the dispute examinatons in the medical treatment field. 


\section{LIST OF LITERATURE AND INFORMATION SOURCES}

\section{Laws and regulations:}

1. The Constitution of the Republic of Latvia. Latvijas Vēstnesis [Latvian Herald], No. 43, 01.07.1993.

2. Convention for the Protection of Human Rights and Fundamental Freedoms. Latvijas Vēstnesis [Latvian Herald], No. 143/144, 13.06.1997.

3. The United Nations Convention on the Rights of the Child is a human rights. Adopted and opened for signature, ratification and accession by General Assembly resolution $44 / 25$ of 20 November 1989 entry into force 2 September 1990. Latvijas Vēstnesis [Latvian Herald], 237(5297).

4. CHARTER OF FUNDAMENTAL RIGHTS OF THE EUROPEAN UNION (2012/C 326/02). Official Journal of the European Union C 326/391.

5. DIRECTIVE 2008/52/EC OF THE EUROPEAN PARLIAMENT AND OF THE COUNCIL of 21 May 2008 on certain aspects of mediation in civil and commercial matters. Official Journal of the European Union. L 136/3.

6. DIRECTIVE 2011/24/EU OF THE EUROPEAN PARLIAMENT AND OF THE COUNCIL of 9 March 2011 on the application of patients' rights in cross-border healthcare. Official Journal of the European Union. L 88/45.

7. REGULATION (EU) 2016/679 OF THE EUROPEAN PARLIAMENT AND OF THE COUNCIL of 27 April 2016 on the protection of natural persons with regard to the processing of personal data and on the free movement of such data, and repealing Directive 95/46/EC (General Data Protection Regulation). Official Journal of the European Union L 119/1.

8. DIRECTIVE 2004/38/EC OF THE EUROPEAN PARLIAMENT AND OF THE COUNCIL of 29 April 2004 on the right of citizens of the Union and their family members to move and reside freely within the territory of the Member States amending Regulation (EEC) No 1612/68 and repealing 
Directives 64/221/EEC, 68/360/EEC, 72/194/EEC, 73/148/EEC, 75/34/EEC, 75/35/EEC, 90/364/EEC, 90/365/EEC and 93/96/ EEC29.04.2004.

9. COUNCIL DIRECTIVE 94/33/EC of 22 June 1994 on the protection of young people at work. Official Journal of the European Union L 216/12.

10. Administrative Procedure Law. Law of the Republic of Latvia. Latvijas Vēstnesis, [Latvian Herald], No 164 (2551).

11. Medical Treatment Law. Law of the Republic of Latvia Latvijas Vēstnesis, [Latvian Herald] No 167/168 (882/883), 01.07.1997.

12. Law on Orphan's Courts: Law of the Republic of Latvia. Latvijas Vēstnesis, [Latvian Herald] No 107, Section 2, 07.07.2006.

13. Law on the Protection of the Children's Rights: Law of the Republic of Latvia Latvijas Vēstnesis, [Latvian Herald] No 199/200 (1260/1261), 08.07.1998.

14. Civil Law: Law of the Republic of Latvia. Latvijas Vēstnesis, [Latvian Herald], 41, 20.02.1937.

15. Criminal Law: Law of the Republic of Latvia. Latvijas Vēstnesis, [Latvian Herald], 199/200. 17.06.1998.

16. Mediation Law: Law of the Republic of Latvia. Latvijas Vēstnesis, [Latvian Herald], No 108 (5168), 18.06.2014.

17. Law on the Rights of Patients. Latvijas Vēstnesis, [Latvian Herald], No 205(4191), 30.12.2009.

18. Sexual and Reproductive Health Law. Latvijas Vēstnesis, [Latvian Herald], No 27 (2602), 19.02.2002.

19. Regulations on the competence of medical practitioners and students who acquire the first or second level professional higher medical education programmes in medical treatment and their theoretical and practical knowledge. Cabinet Regulations No 268 of March 24, 2009. Latvijas Vēstnesis, [Latvian Herald], No 58, Subclause 10.58, 16.04.2009. 


\section{Literature:}

20. Ašnevica, S., Gusarova, A., Lieljuksis A., et al. Medicīnas tiesības (Eng. Medicat Law). Rīga: Tiesu nama aǵentūra, 2015, 292 lpp.

21. Besson, S. The Principle of Non-Discrimination in the Convention on the Rights of the Child. The International Journal of Children s Rights, No 13, 2005, 433-461.

22. Bowyer, L. The ethical grounds for the best interest of the child. Cambridge Quarterly of Healthcare Ethics, 2016, Vol 25, No 1, p. 63-69.

23. Civilprocesa likuma komentāri. II daḷa (29.-60. nodaļa) (Eng. Comments on the Civil Procedure Law. Part II (Sections 29-60). Sagat. aut. kol. K. Torgāna zina. red. Rīga: Tiesu namu aǵentūra, 2012, 591 lpp.

24. Hall, M. A., Bobinski, M. A., Orentlicher, D. Medical liability and treatment relationships. $2^{\text {nd }}$ ed. $2008,433$.

25. Hipokrātiskie raksti: Izlase (Eng. Hippocratic Articles: Favorites). A. Gailes un A. van Hofas tulkojums no sengrieķu valodas, ievads un komentāri. Rīga: Liepnieks \& Rītups, 2003, 449.

26. Ilustrētā svešvārdu vārdnīca (Eng. Illustrated Foreign Word Dictionary). Rīga: Avots, 2005, 891.

27. Imran, M., Samad, S., Maaz, M., Qadeer, A., Najmi, A. K., Aqil, M. Hippocratic oath and conversion of ethico-regulatory aspects onto doctors as a physician, private individual and a clinical investigator. J Midlife Health, 2013, Vol 4, No 4, 203-209.

28. Trosens A., Hofmans R., Rotfišere Dorisa B. Mediācija. Mediācijas pamati teorijā un praksē (Eng. Mediation. Basics of mediation in theory and practice). VAS “Tiesu namu aǵentūra”, 2007, 183.

29. Медведев, Г. П. Этика социальной работы (Eng. Ethics of Social Work). М.: ВЛАДОС, 1999, с.206 
30. Никонов, К. Современные теоретические аспекты института международно-правовой защиты и поощрения прав ребенка (Eng. Modern theoretical aspects of the institution of international legal protection and promotion of the rights of the child). Московский журнал международного права, 2009, № 1, 95-96.

31. Якобсон, В. А. Законы Хаммурапи как источник по истории древней Месопотамии (Eng. The laws of Hammurabi as a source on the history of ancient Mesopotamia): Дис. докт. ист. наук. Ленинградское отделение Института востоковедения, 1987. 94-96.

\section{Other sources:}

32. Latvijas Republikas Satversmes tiesas 2005. gada 22. decembra sprieduma lietā Nr. 2005-19-01 (Eng. Judgment of the Constitutional Court of the Republic of Latvia of 22 December, 2005 in case No 2005-19-01). Available: https://likumi.lv/doc.php?id=124748\&from=off [accessed on 13.08.2018].

33. Apvienoto Nācijas organizācijas Bērnu tiesību komiteja. Vispārējais komentārs Nr.12 (2009). Bērna tiesības tikt uzklausītām. 2009. gada 20. jūlijā (Eng. United Nations Committee on the Rights of the Child. General Comment No 12 (2009). Right of the child to be heard. July 20, 2009). Available: http://www.lm.gov.lv/lv/index.php?option=com_content\& view $=$ article $\& i d=81194$ [accessed on 16.10. 2018]

34. Apvienoto Nāciju organizācijas Vispārējā cilvēktiesību deklarācija (Eng. United Nations Universal Declaration of Human Rights). Available: http://www.tiesibsargs.lv/lv/pages/tiesibu-akti/ano-dokumenti/anovispareja-cilvektiesibu-deklaracija [accessed on 16.08. 2018].

35. Charles, D., Shaw, Kalo I. A background for national quality policies in health systems. World Health Organisation, 2012. Available: http://apps.who.int/iris/bitstream/handle/10665/107458/E77983.pdf?sequen ce $=1 \&$ isAllowed=y [accessed on 10.01.2019]. 
36. Children's Rights History. Historical overview of the Children's rights evolution. Available: https://www.humanium.org/en/childrens-rights-history [accessed on 13.04.2018].

37. Collins, A., Britten, S. A., Ruusuvuori, J. Participation in health care consultations: Qualitative perspectives: Qualitative perspectives. UK Higher Education OUP Humanities \& Social Sciences Health \& Social Welfare. McGraw-Hill Education (UK), 2007, ProQuest Ebook Central. Available: https://ebookcentral-proquest-com.db.rsu.lv/lib/rsubebooks/detail.action?docID $=316260$

38. Committee on the Rights of the child. Thirty-fourth session September 19October 32003 GENERAL COMMENT No 5 (2003) General measures of implementation of the Convention on the Rights of the Child (arts. 4, 42 and 44, para. 6). Available: http://www.refworld.org/docid/4538834f11.html [accessed on 13.08.2018].

39. Freckelton, I. Medico-legal ramifications of the evolving doctor-patient relationship. Medicine and Law. World Association for Medical Law Med Law, 2018, vol 37, No 1, 61-86. Available:http://wafml.memberlodge.org/ resources/Documents/WAML\%20Journal\%20Volume\%2037\%20Number \%201.pdf [accessed on 07.11.2018].

40. HOPE - European Hospital and Healthcare Federation. 2012. Mediation in Healthcare. Available: https://www.mediate.com/pdf/91_HOPE_ Publication-Mediation_December_2012.pdf [accessed on 09.12.2018].

41. Human Rights Committee's General Comment 18 on Non-Discrimination, 10/11/1989, HRI/GEN/1/Rev. 5, reproduced in Compilation of General Comments and General Recommendations adopted by Human Rights Treaty Bodies, UN Doc. HRI/GEN/1. Available: http://www.equaLVightstrust.org/ ertdocumentbank/Human\%20Rights\%20Committee,\%20General\%20Com ment\%2018.pdf [accessed on 11.12.2018]. 
42. Infografika "Soli pa solim": Mediācijas priekšrocības. Mediācijas padome (Eng. Infographics "Step-by-Step": Benefits of Mediation. Mediation Board). Available: http://www.mediacija.lv/?Kas_ir_medi\%C4\%81cija\%3F [accessed on 14.03.2019].

43. Latvijas ārstu biedrības statūti (Eng. Statutes of the Latvian Medical Association). Latvijas ārstu biedrības tīmekḷa vietne, 12.03.1993. Available: http://www.arstubiedriba.lv/statuti/ [accessed on 21.11.2018].

44. Nacionālais veselības dienests. Pētījums par pacientu apmierinātību ar veselības aprūpes pakalpojumu kvalitāti (Eng. National Health Service. Study on patient satisfaction with quality of health care services). Rìga, 2018. Available:

http://petijumi.mk.gov.lv/sites/default/files/title_file/Zinojums_Pacientu_ap mierinatiba_ar_veselibas_aprupes_pakalp_kvalitati.pdf [accessed on 18.02.2019].

45. Neuberger, J. Do we need a new word for patients? Let's do away with “patients"”. BMJ, 26.06.1999, Vol. 318, No 7200, p.1756-1757. Available: https://www.ncbi.nlm.nih.gov/pmc/articles/PMC1116090/ [accessed on 09.07.2018].

46. Pobjoy, J. M. The Best Interests of the Child Principle as an Independent Source of International Protection. International Comparative Law Quarterly, 2015, Vol. 64, No 2, p. 327-363. Available: SSRN: https://ssrn.com/abstract=2679568 [accessed on 09.10.2018].

47. Putniņa, A., Brants, M. Pacientu apmierinātība ar veselības aprūpes pakalpojumu kvalitāti: Pētījums (Eng. Patient Satisfaction with the Quality of Healthcare Services: A Study). Rīga: SIA «Projektu un kvalitātes vadība» un SIA «Aptauju Centrs», 2019 Available: http://www.vm.gov.lv/ images/userfiles/Prezent\%C4\%81cija_VM.pdf [accessed on 18.02.2019]. 
48. Sheea Sybblis. Mediation in the healthcare system: Creative problem solving, 6 Pepp. Disp. Resol. L.J., 2006, No 3. Available: http://digitalcommons.pepperdine.edu/drlj/vol6/iss $3 / 6$

49. Slawomirski, L., Auraaen, A., Klazinga, N. The economics of patient safety. Strenghtening a value-based approach to reducing patient harm at national level. OECD, 2017, Grant N.DI161105. Available: https:// www.bundesgesundheitsministerium.de/fileadmin/Dateien/3_Downloads/P/ Patientensicherheit/The_Economics_of_patient_safety_Web.pdf [accessed on 10.01.2019].

50. Tallis, R. Do we need a new word for patients? Commentary: leave well alone. BMJ. 1999, Vol 318, No 7200, p. 1757-1758. Available: https://www.ncbi.nlm.nih.gov/pmc/articles/PMC1116090/ [accessed on 12.06.2018].

51. Thompson, A. G. The meaning of patient involvement and participation in health care consultations: A taxonomy. Soc Sci Med, 2007, Vol 64, No 6, p. 1297-310. Available: https://www.ncbi.nlm.nih.gov/pubmed/17174016 [accessed on 10.11.2018].

52. Townsend Davis, E. Judicial limitations on parental autonomy in the medical treatment of minors: Custody of a minor, Mass, 379 N.E.2d 1053 (1978), aff'd on rehearing, Mass, 393 N.E.2d 836 (1979), Neb. L. Rev., 1980, Vol 59, No 4, p 1110. Available: https://digitalcommons.unl.edu/nLV/vol59/iss4/7 [accessed on 09.07.2018].

53. World Medical Association. Members. Available: https://www.wma.net/ who-we-are/members/members-list-printable/ [accessed on 09.12.2018]. 